\title{
O GÊNERo CRoton (EuphorbiaCEAe) NA Microrregião do VALE do Ipanema, Pernambuco, Brasil
}

\author{
Juliana Santos Silval, Margareth Ferreira de Sales ${ }^{2}$ \\ \& Daniela Santos Carneiro-Torres ${ }^{3}$
}

\section{RESUMO}

(O gênero Croton (Euphorbiaceae) na microrregião do Vale do Ipanema, Pernambuco, Brasil) O gênero Croton é o segundo maior e mais diverso em Euphorbiaceae, possuindo cerca de 1.200 espécies, difundidas predominantemente no continente americano. Este estudo foi baseado na análise morfológica de materiais herborizados e na observação das plantas em campo. Foram registradas 15 espécies, apenas $C$. heliotropiifolius com ampla distribuição na área de estudo, ocorrendo em vegetação de caatinga. Croton adamantinus, C. corchoropsis, C. nummularius, C. rudolphianus e $C$. virgultosus são encontradas apenas no complexo arenítico das serras da chapada de São José, em Buíque, crescendo em vegetação rupestre. São fornecidos chave para identificação, comentários sobre as afinidades entre os táxons e distribuição geográfica, bem como ilustrações de todas as espécies estudadas. Palavras-chave: Caatinga, Crotonoideae, florística, parque nacional, Nordeste, taxonomia.

\section{Abstract}

(The genus Croton (Euphorbiaceae) from the microregion of Ipanema Valley, Pernambuco, Brazil) Croton is the second largest genus in Euphorbiaceae, with about 1,200 species, distributed predominantly in the Americas. This study was based on herbarium material and field observations. A total of 15 species was recognized, only C. heliotropiifolius with wide distribution in the study area, occurring in caatinga vegetation. Croton adamantinus, C. corchoropsis, $C$. nummularius, $C$. rudolphianus, and $C$. virgultosus are found only in the sandstone complex of São José plateau, Buíque, growing up in rocky vegetation. Identification keys, descriptions, comments about morphological relationships and geographic distribution, and illustrations of species are provided.

Key words: Caatinga, Crotonoideae, floristics, national park, Northeast, taxonomy.

\section{INTRODUÇÃO}

Croton é o segundo maior gênero de Euphorbiaceae, com aproximadamente 1.200 espécies distribuídas predominantemente no continente americano. Com cerca de 300 espécies, o Brasil é um dos principais centros de diversidade do gênero, que está representado nos mais variados ambientes e tipos vegetacionais (Berry et al. 2005).

O gênero recebeu atenção de diversos estudiosos (e.g., Baillon 1858; Mueller 1865, 1866, 1873; Bentham 1880), destacando-se Webster (1993), que propôs a classificação infragenérica mais recente para o gênero. Desde o tratamento de Mueller(1873), não existe uma revisão de Croton para o Brasil, o que dificulta o reconhecimento de suas espécies. Embora constitua o principal ponto de partida para estudos sobre o gênero, a Flora brasiliensis (Mueller 1873) se encontra desatualizada devido às recentes sinonimizações, publicações de novos táxons e mudanças na sua classificação infragenérica. Recentemente, Gomes (2006) revisou a seção Argyroglossum Baill. para a América do Sul, citando nove espécies para o Brasil, e Lima \& Pirani (2008) estudaram a seção Lamprocroton (Müll. Arg.) Pax, registrando 21 espécies brasileiras. Estudos tratando de Croton no Nordeste ainda estão dispersos na literatura, ficando restritos a trabalhos florísticos e/ou fitossociológicos (Cordeiro 1995; Lucena 2001; Carneiro-Torres et al. 2002).

A microrregião do Vale do Ipanema, com cerca $5.288 \mathrm{~km}^{2}$, localiza-se no estado de Pernambuco, abrangendo seis municípios.

Artigo recebido em 05/2009. Aceito para publicação em 11/2009.

${ }^{1}$ Programa de Pós-Graduação em Botânica da Universidade Federal Rural de Pernambuco (Bolsista CNPq 130955/2007-8). Autor para correspondência: jullybandeira@ hotmail.com

${ }^{2}$ Universidade Federal Rural de Pernambuco, Depto. Biologia, R. D. Manoel de Medeiros s/n, 52171-900, Dois Irmãos, Recife, PE, Brasil.

${ }^{3}$ Universidade Estadual do Sudoeste da Bahia, Campus Jequié, R. José Moreira Sobrinho s/n, 45206-190, Jequiezinho, Jequié, BA, Brasil. 
Abriga, ainda, dois importantes parques: o Parque Municipal da Pedra Furada e o Parque Nacional do Vale do Catimbau (PNVC). O PNVC destaca-se por ser o segundo maior parque arqueológico do Brasil, pela presença de sítios datados de aproximadamente 6.000 anos. Outro aspecto relevante dessa microrregião é a presença de um mosaico de diferentes tipos vegetacionais com floras características. A composição florística e os aspectos vegetacionais desses diferentes ambientes ainda são pouco conhecidos (Figueirêdo et al. 2000; Andrade et al. 2004; Gomes et al. 2006), mas já há indícios apontando para uma flora bastante rica e diversificada, composta por mais de 370 espécies de angiospermas.

Diante da expressiva importância de Croton, este estudo teve por objetivo conhecer a diversidade do gênero na microrregião do Vale do Ipanema, com intuito de facilitar a delimitação e o reconhecimento das espécies desta região, bem como fornecer subsídios para o manejo de suas unidades de conservação.

\section{Material e Métodos}

\section{Área de estudo}

A microrregião do Vale do Ipanema situase em Pernambuco, na zona fitogeográfica das Caatingas (subzona doAgreste), a aproximadamente $340 \mathrm{~km}$ de Recife, abrangendo os municípios de Águas Belas, Buíque, Itaíba, Pedra, Tupanatinga e Venturosa (Fig. 1; Silva \& Sales 2008). É banhada pelas bacias do rio Ipanema e do rio Moxotó, que juntas correspondem a mais de $15 \%$ da área do estado. Do ponto de vista geomorfológico, está inserida no Planalto da Borborema, apresentando relevo ondulado a fortemente ondulado, com altitudes variando de 650 a 1.000 m (CPRM 2005). Os solos são rasos a profundos, predominando Planossolo e Podzólico nas encostas e circundando a área serrana e Litólicos no topo das serras. O clima é do tipo tropical chuvoso, com verão seco (CPRM 2005). O município de Buíque, com uma área de $1.378 \mathrm{~km}^{2}$, destaca-se por ser o maior município da microrregião (CONDEPE 1993). Além disso, nele está situada a maior

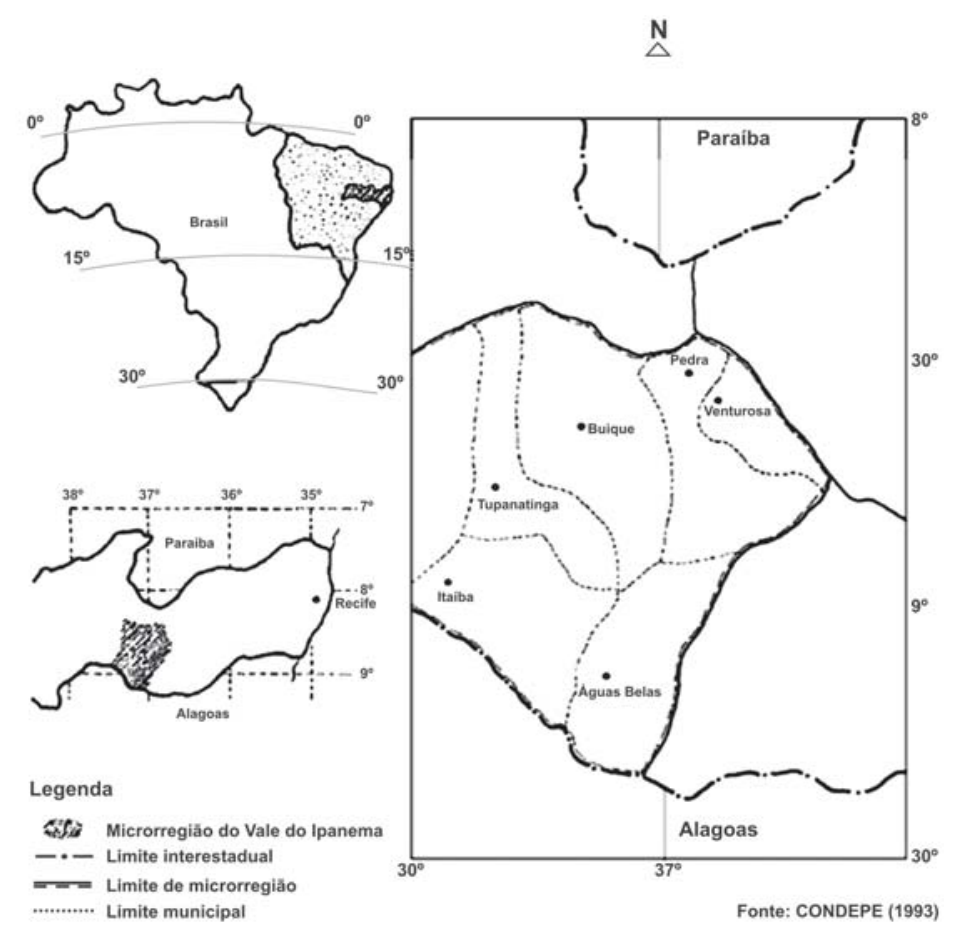

Figura 1 - Mapa da microrregião do Vale do Ipanema.

Figure 1 - Map of microregion of Ipanema Valley. 
parte da chapada de São José, que possui padrões de vegetação bastante complexos, compostos por tipos que variam de subcaducifólias a perenifólias, com flora e fisionomias distintas da formação vegetacional de caatinga encontrada nos demais municípios do Vale do Ipanema (Gomes et al. 2006). Para esta chapada foram reconhecidas três tipologias de vegetação distintas: caducifólia arbustiva espinhosa (Figueirêdo et al. 2000), perenifólia arbustiva (Andrade et al. 2004) e rupestre.

\section{Estudo taxonômico}

Entre 2007 e 2008, foram realizadas coletas nas diferentes áreas da microrregião do Vale do Ipanema. O material foi depositado no acervo do Herbário Professor Vasconcelos Sobrinho (PEUFR) da Universidade Federal Rural de Pernambuco. A identificação dos táxons está baseada em literatura e na fotografia de coleções-tipo. Para padronizar os termos das estruturas vegetativas e reprodutivas foi adotado Harris \& Harris (1994). Foram consultados os herbários BHCB, ESA, ESAL, HST, HUEFS, IAN, IBGE, IPA, PEUFR, R, UEC, UFP, UB e VIC. As informações contidas nas exsicatas desses herbários auxiliaram nos comentários de distribuição das espécies.

\section{Resultados e Discussão}

Croton L., Sp. pl. 2: 1004. 1753.

Árvores, arbustos, subarbustos, menos frequentemente ervas ou trepadeiras, monóicos ou diócos; indumento de tricomas estrelados, dendríticos, fasciculados, glandulares, lepidotos, simples ou estados intermediários entre estes. Estípulas geralmente presentes, algumas vezes pequenas ou inconspícuas. Folhas simples, alternas, às vezes opostas ou verticiladas, pecioladas, frequentemente com glândulas na porção distal do pecíolo, na superfície superior, no ponto de inserção da lâmina no pecíolo ou próximo ao ponto (acropeciolar); na porção distal do pecíolo, na superfície inferior, bem próximo à lâmina (basilaminar); ou ainda na margem das folhas (marginal). Inflorescências terminais, raramente axilares, em geral racemosas (geralmente racemos ou pseudoracemos, neste caso monotirsos onde as címulas laterais são contraídas), uni ou bissexuadas, flores pistiladas dispostas na região proximal e flores estaminadas na região distal do eixo. Flores estaminadas pediceladas, diclamídeas, actinomorfas; sépalas (4)5(6), livres; pétalas (4)5(6), raramente ausentes, livres; disco inteiro ou dividido em segmentos opostos às sépalas; estames 5 a muitos, filetes livres, encurvados no botão, anteras basifixas, introrsas, 2-loculares, rimosas. Flores pistiladas sésseis ou curtamente pediceladas, monoclamídeas ou diclamídeas, actinomorfas; sépalas 5 ou 6, livres, valvares ou imbricadas; pétalas 5 ou 6 , geralmente ausentes ou muito reduzidas; disco inteiro ou divido em segmentos opostos às sépalas; ovário 3-carpelar, 3-locular, 1 óvulo por lóculo, placentação axial; estiletes 3, livres ou unidos, inteiros, bífidos ou multífidos. Fruto cápsula septicida-loculicida de deiscência explosiva; columela com ápice inteiro ou tripartido; sementes carunculadas, endospermadas, plana na face ventral e convexa na face dorsal; testa lisa ou ornamentada; embrião reto, com cotilédones planos, membranáceos, arredondados, mais largos do que a radícula.

Croton é um grupo funcionalmente importante dentro do ecossistema terrestre. Várias de suas espécies são pioneiras, colonizando locais perturbados, tais como beira de estradas, margem de rios e clareiras de matas. Essa característica se deve principalmente a produção massiva de flores e frutos durante a maior parte do ano, o que torna suas espécies candidatas para a restauração de áreas degradadas (Lima \& Pirani 2008). Além disso, Croton possui forte potencial econômico, especialmente para a indústria farmacêutica, devido aos diversos metabólitos secundários, como alcalóides, flavonóides e terpenóides (Rizsck 1987; Payo et al. 2001), que conferem propriedades terapêuticas a muitas espécies. 


\section{Chave para as espécies de Croton da microrregião do Vale do Ipanema}

1. Ramos com tricomas estrelado-lepidotos a dentado-lepidotos; sépalas das flores pistiladas reduplicado-valvares.

2. Limbo 9-17 × 7,5-8 cm, largamente oval, face inferior esverdeada; disco das flores estaminadas com cinco glândulas, glabro; estiletes unidos em coluna

3. C. blanchetianus

2'. Limbo 5-8,4 × 1-2 cm, lanceolado a elíptico, face inferior uniformemente prateada a discretamente amarelada; disco das flores estaminadas pentalobado, lepidoto; estiletes unidos apenas na base

2. C. argyrophyllus

1'. Ramos com tricomas estrelados, estrelado-porrectos, raramente entremeados com estreladorotados, fasciculados, dendríticos, multirradiado-porrectos ou simples; sépalas das flores pistiladas valvares, não reduplicadas.

3. Estiletes multífidos.

4. Estípulas sem glândulas; nervação hifódroma; brácteas inteiras; filetes glabros; pétalas das flores pistiladas filiformes

4. C. corchoropsis

4'. Estípulas ciniado-glandulares; nervação eucamptódroma ou broquidódroma; brácteas laciniado-glandulares; filetes vilosos; pétalas das flores pistiladas ausentes.

5. Limbo 0,2-1 cm compr., orbicular 11. C. nummularius

5'. Limbo 2-6,4 cm compr., oval a oval-elíptico.

6. Sépalas e pétalas das flores estaminadas com glândulas punctiformes translúcidas douradas; face externa das sépalas das flores pistiladas tomentosa; ovário tomentoso; estiletes ascendentes; cápsula tomentosa ....

14. C. urticifolius

6'. Sépalas e pétalas das flores estaminadas sem glândulas; face externa das sépalas das flores pistiladas glabrescente; ovário glabrescentes; estiletes patentes; cápsula glabra

12. C. rudolphianus

3'. Estiletes 2-fidos.

7. Inflorescência com espaço estéril entre as címulas de flores estaminadas e de flores pistiladas, exibindo a porção mediana da raque sem flores; flores pistiladas com seis sépalas. 10. C. lundianus

7'. Inflorescência sem espaço estéril entre as címulas de flores estaminadas e de flores pistiladas; flores pistiladas com cinco sépalas.

8. Brácteas com glândulas.

9. Ramos hirsutos; glândulas das brácteas longo-estipitadas (ca. 3 mm compr.) 9. C. hirtus

9'. Ramos tomentosos; glândulas das brácteas sésseis 6. C. glandulosus

8'. Brácteas sem glândulas.

10. Limbo com margem inteira a esparsamente serrilhada.

11. Pecíolo normalmente sem glândulas ou, quando presentes, inconspícuas (0,2-0,3 mm diâm.), sésseis, globosas; columela do fruto com ápice tripartido após a deiscência

8. C. heliotropiifolius

11'. Pecíolo com glândulas conspícuas (0,6-1,2 mm compr.), estipitadas, cilíndricas ou discóides; columela do fruto com ápice inteiro após a deiscência.

12. Glândulas do pecíolo discóides; flores pistiladas sésseis; estiletes patentes

5. C. echioides

12'. Glândulas do pecíolo cilíndricas; flores pistiladas pediceladas; estiletes ascendentes

13. C. tetradenius 
10'. Limbo com margem crenada, denteada, serreada, serreado-glandular ou bisserreada, glandular.

13. Planta fortemente aromática, aroma de canela perceptível até em material herborizado; limbo elíptico; brácteas estreitamente oblongas; pétalas das flores estaminadas com glândulas punctiformes translúcidas douradas; filetes vilosos; sépalas das flores pistiladas lanceoladas, internamente glabras; pétalas das flores pistiladas ausentes 7. C. grewioides

13'. Planta apenas ligeiramente aromática; limbo oval; brácteas lineares; pétalas das flores estaminadas sem glândulas; filetes glabros; sépalas das flores pistiladas variando de elípticas a ovais, internamente tomentosas ou vilosas no ápice; pétalas das flores pistiladas inconspícuas, filiformes.

14. Inflorescências $0,7-2,5 \mathrm{~cm}$ compr.; sépalas das flores estaminadas com glândulas punctiformes translúcidas douradas 1. C. adamantinus

14'. Inflorescências 8-9,5 cm compr.; sépalas das flores estaminadas sem glândulas .....

15. C. virgultosus

1. Croton adamantinus Müll. Arg. in Martius \& Eichler, Fl. bras. 11(2): 115. 1873.

Fig. 2a-g

Arbustos, 0,8-1,5 m alt., monóicos, ligeiramente aromáticos, látex translúcido. Indumento tomentoso; tricomas estreladoporrectos e fasciculados, esbranquiçados a amarelados. Ramos enegrecidos. Folhas alternas; estípulas 2,2-4,8 ×0,3-1 mm, persistentes, não foliáceas, lineares, sem glândulas; pecíolos 0,3-1 cm compr., não viscosos; glândulas 2, 0,4-0,6 mm diâm., basilaminares, estipitadas, pateliformes; lâmina 2-5×2-2,8 cm, cartácea, concolor, oval, base cordada, ápice agudo, margem denteado-glandular, glândulas globosas no ápice dos dentes e estipitadas, pateliformes entre os dentes, face superior pubescente, face inferior lanosa; nervação eucamptódroma. Inflorescência $0,7-2,5 \mathrm{~cm}$ compr., solitária, espiciforme a glomeruliforme, sem espaço estéril entre as címulas de flores estaminadas e de flores pistiladas; brácteas 1-3 $\times 0,2-0,4 \mathrm{~mm}$, inteiras, lineares, sem glândulas. Flores estaminadas 1,5-3 mm compr.; pedicelo 1-2,2 mm compr.; sépalas 5, 1,9-2,1×ca. $1 \mathrm{~mm}$, valvares, oblanceoladas a ovais, externamente tomentosas, internamente glabras, glândulas punctiformes translúcidas douradas; pétalas 5, $1,8-2,2 \times 0,8-1 \mathrm{~mm}$, valvares, ovais, ciliadas, externamente glabras, internamente vilosas na base, sem glândulas; estames 10,2-3 mm compr., filetes glabros, receptáculo viloso; disco inteiro, pentalobado, lobos transversalmente elipsóides, glabros. Flores pistiladas 4-6 mm compr.; pedicelo
0,7-1 mm compr.; sépalas 5, 2-5 × 1-1,2 mm, valvares, não reduplicadas, iguais entre si, elípticas a ovais, unidas por $1 / 4$ de seu comprimento, externamente tomentosas, internamente tomentas no ápice, sem glândulas; pétalas 5, inconspícuas, filiformes; ovário 1-2 × ca. $2 \mathrm{~mm}$, oblato, tomentoso; estiletes 2-fidos, ligeiramente unidos na base, ascendentes; disco inteiro, pentalobado, lobos transversalmente elipsóides, glabros. Cápsula 6-7 × 6-8 mm, orbicular, marrom, pubescente-tomentosa; columela com ápice inteiro após a deiscência do fruto. Sementes 5-6 $\times$ ca. $3 \mathrm{~mm}$, oblongas, rugosas, amarronzadas.

Material selecionado: Buíque: Estrada do Fortuoso, 11.II.2008, fl. e fr., J.S. Silva et al. 371 (PEUFR); estrada para o Paraíso Selvagem, 12.II.2008, fl., J.S. Silva et al. 386 (PEUFR); Pedra do Cachorro, 13.II.2008, fl., J.S. Silva et al. 400 (PEUFR); Serra das Torres, 28.V.2007, fl., D.S. Carneiro-Torres et al. 955 (HUEFS); Serra do Catimbau, Trilha Caiana, 30.VII.2005, fl., M.F.A. Lucena et al. 1066 (UFP).

Está restrita ao semi-árido brasileiro, ocorrendo na Bahia, Ceará, Pernambuco, Piauí, Rio Grande do Norte e Sergipe, estendendo-se até o norte de Minas Gerais (Carneiro-Torres 2009). No Vale do Ipanema, foi coletada apenas em Buíque, no complexo arenítico da chapada de São José, onde é bastante frequente sobre afloramentos rochosos e em solos arenosos, esbranquiçados ou alaranjados, em altitudes que variam de 600 a $800 \mathrm{~m}$.

Assemelha-se a Croton virgultosus por ambas possuírem hábito arbustivo, tricomas estrelado-porrectos, base das folhas cordada, 
glândulas estipitadas, pateliformes, basilaminares e estiletes bífidos. Entretanto, C. adamantinus possui inflorescências curtas (0,7-2,5 vs. 8$9,5 \mathrm{~cm}$ compr.), variando de espiciforme a glomeruliforme (vs. flores esparsas ao longo do eixo) e glândulas punctiformes nas sépalas das flores estaminadas (ausentes em C. virgultosus). Além disso, C. virgultosus parece estar associada à floresta estacional.

Foi encontrada com flores e frutos em fevereiro, junho e setembro. Devido à grande quantidade de abelhas observadas nas flores, parece tratar-se de uma espécie melífera.

2. Croton argyrophyllus Kunth in Humboldt, Bonpland \& Kunth, Nov. gen. sp. (quarto ed.) 2: 68. 1817.

Fig. 2h-n

Arbustos, 1,6-5 m alt., monóicos, látex ausente. Indumento lepidoto; tricomas estrelado-lepidotos a dentado-lepidotos, esbranquiados, amarelados a prateados. Ramos castanhos, glabrescentes a densamente indumentados. Folhas alternas a subopostas, frequentemente congestas no ápice dos ramos; estípulas 3,1-6,8 ×0,5-1 mm, persistentes, nãofoliceas, estreitamente lanceoladas, sem glândulas; pecíolos $0,5-1 \mathrm{~cm}$ compr., não viscosos, sem glândulas; lâmina 5-8,4×1-2 cm, membranácea, discolor, lanceolada a elíptica, base cordada, ápice acuminado, margem inteira, face superior verde, puberulenta, face inferior uniformemente prateada a discretamente amarelada, lepidota; nervação eucamptódroma. Inflorescência 2,3-12 cm compr., solitária, racemiforme, sem espaço estéril entre as címulas de flores estaminadas e de flores pistiladas; brácteas 2-3 $20,4-1 \mathrm{~mm}, 1-3$ por flor, inteiras, elípticas, sem glândulas. Flores estaminadas 4 5 mm compr.; pedicelo 2-3 mm compr.; sépalas 5, 2-3 $\times 1-2 \mathrm{~mm}$, valvares, ovais, externamente lepidotas, internamente glabras, sem glândulas; pétalas 5, 2-2,6×0,5-1 mm, valvares, elípticas, ciliadas, externamente seríceas a glabrescentes, internamente vilosas, sem glândulas; estames 13-16, 3-3,6 mm compr., filetes vilosopubescentes; receptáculo tomentoso, tricomas estrelado-porrectos; disco inteiro, pentalobado, lobos obovóides, lepidotos. Flores pistiladas 3-
$7 \mathrm{~mm}$ compr.; pedicelo 0,5-1 $\mathrm{mm}$ compr.; sépalas $5,2,8-5 \times 1-3 \mathrm{~mm}$, reduplicadovalvares, iguais entre si, ovais, unidas por $1 / 2$ do seu comprimento, externamente lepidotos, internamente pubescentes no ápice, sem glândulas; pétalas ausentes; ovário 1,8-2×ca. $1 \mathrm{~mm}$, oblongóide, lepidoto; estiletes multífidos, unidos apenas na base, ascendentes; disco inteiro, cupuliforme, lepidoto. Cápsula 6-6,5× 4-5 mm, ovóide, prateada, lepidota; columela com ápice inteiro após a deiscência do fruto. Sementes 4,5-4,8 × $3 \mathrm{~mm}$, elipsóides, lisas, amarronzadas.

Material selecionado: Buíque: fazenda Laranjeiras, 10.I.1996, fl. e fr., W. Andrade et al. 267 (PEUFR); Pedra do Cachorro, 13.II.2008, fl., J.S. Silva et al 399 (PEUFR); sítio Pititi, 11/I/1996, fl. e fr., A.P.S. Gomes et al. 15 (PEUFR). Pedra: 30.III.1991, fl., M. Pessoa (PEUFR 12420). Venturosa: Parque Municipal da Pedra Furada, 17.I.1998, fl., K. Costa \& M.J.N. Rodal 7 (PEUFR).

Croton argyrophyllus é amplamente distribuída em ambientes semi-áridos da América do Sul (Brasil, Colômbia, Bolvia e Venezuela) (Gomes 2006). No Brasil, referida para as Regiões Norte (Roraima e Rondônia) e Nordeste (Alagoas, Bahia, Ceará, Paraíba, Pernambuco, Piauí e Sergipe), em vegetações de caatinga, carrasco e cerrado (CarneiroTorres 2009). Na área de estudo, forma extensas populações sobre solos arenosos ou pedregosos em vegetação de caatinga.

Em campo é de fácil reconhecimento devido coloração prateada da face abaxial de suas folhas, dada pelo adensamento dos tricomas lepidotos, prateados. Assemelha-se a Croton tricolor Klotzsch ex Baill, com a qual é frequentemente confundida. Entretanto, diferencia-se principalmente pelos tricomas uniformemente prateados, disco das flores pistiladas cupuliforme, lepidoto em ambas as flores e sementes com testa lisa. Enquanto em C. tricolor, o indumento é constituído por tricomas ferrugíneos a ferrugíneo-alaranjados, disco das flores pistiladas pentalobado e a testa da semente é papiloso-rugosa.

Foi coletada com flores em janeiro, fevereiro e março e com frutos apenas em janeiro. É popularmente conhecida por marmeleiro. 


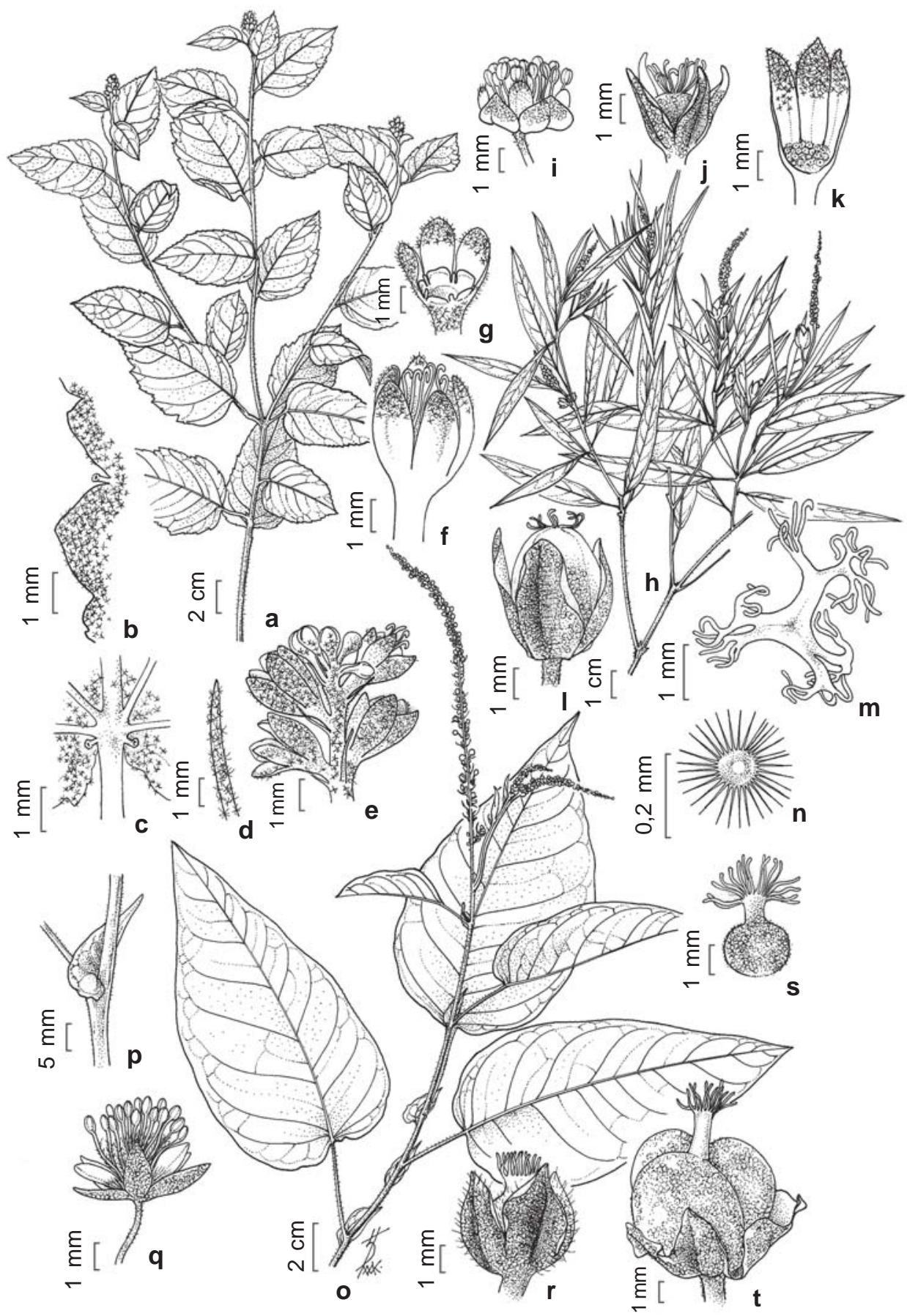

Figura 2 - a-g. Croton adamantinus - a. ramo; b. detalhe de uma glândula entre os dentes da margem do limbo (lâmina); c. glândulas basilaminares; d. bráctea; e. inflorescência; f. flor pistilada; g. disco da flor pistilada (J.S. Silva et al. 270). h-n. Croton argyrophyllus - h. ramo; i. flor estaminada; j. flor pistilada; k. disco da flor pistilada encoberto por tricomas; 1. fruto; m. estiletes; n. tricoma (W. Andrade et al. 267). o-t. Croton blanchetianus - o. ramo; p. estípula; q. flor estaminada; r. flor pistilada; s. gineceu; t. fruto (Santos $s / n$ UFP 39344).

Figure 2 - a-g. Croton adamantinus - a. branch; b. leaf margin with marginal glands; c. base of leaf blade with glands; d. bract; e. inflorescence; f. pistillate flower; g. disk of the pistillate flower (J.S. Silva et al. 270). h-n. Croton argyrophyllus - h. branch; i. staminate flower; j. pistillate flower; k. disk of the pistillate flower covered by trichomas; 1. fruit; m. styles; n. trichomes (W. Andrade et al. 267). o-t. Croton blanchetianus - o. branch; p. stipule; q. staminate flower; r. pistillate flower; s. gynoecium; t. fruit (Santos s/n UFP 39344). 
3. Croton blanchetianus Baill., Adansonia 4: 301. 1864.

Fig. 2o- $\mathrm{t}$

Arbustos, 1-6 m alt., monóicos, látex incolor. Indumento lepidoto; tricomas estreladolepidotos a dentado-lepidotos esbranquiçados. Ramos castanhos a acinzentados. Folhas alternas; estípulas 10-35×3-10 mm, persistentes, foliáceas, lineares a auriculado-reniformes, sem glândulas; pecíolos 1-1,5 cm compr., não viscosos, sem glândulas; lâmina 9-17 × 7,5-8 cm, membranácea, concolor, largamente oval, base cordada, ápice agudo, margem inteira, face superior pubescente-puberulenta, face inferior tomentosa; nervação eucamptódroma. Inflorescência 6-23 cm compr., solitária, racemiforme, sem espaço estéril entre as címulas de flores estaminadas e de flores pistiladas; brácteas $1-3 \times 0,1-0,3 \mathrm{~mm}, 1-3$ por flores, inteiras, lineares, sem glândulas. Flores estaminadas 3-5 mm compr.; pedicelo 3-7 mm compr.; sépalas 5, 2-3×ca. $2 \mathrm{~mm}$, valvares, ovais, externamente lepidotas, internamente glabras, sem glândulas; pétalas 5, 2,5-3,2 × 1-1,3 mm, valvares, elípticas a obovais, não ciliadas, externamente glabras a tomentosas, internamente velutino-vilosas, sem glândulas; estames 15-16, 2-4,2 mm compr., filetes velutinos, receptáculo glabro; disco com 5 glândulas, ovóides, glabras. Flores pistiladas 5-7 mm compr.; pedicelo 2-4 mm compr.; sépalas 5, 4-7 × 3-3,3 mm, reduplicado-valvares, iguais entre si, ovais, unidas por aproximadamente $1 / 2$ do seu comprimento, externamente lepidotos, internamente pubescentes no ápice, sem glândulas; pétalas ausentes; ovário 2-2,5 × 2-2,5 mm, orbicular, lepidoto; estilete multífido, unidos em coluna, ascendentes; disco inteiro, pentalobado, lobos transversalmente elipsóides, glabros. Cápsula 5-5,5 × 4-5 mm, oblata, transversalmente trilobada, castanha, lepidota; columela com ápice inteiro após a deiscência do fruto. Sementes $4-6 \times$ ca. $3 \mathrm{~mm}$, elipsóides, lisas, enegrecidas.

Material examinado: Águas Belas: próximo a Aldeia do Ouricuri, 7.VI.2002, fl., Santos s.n (UFP 39344).

Material adicional selecionado: BRASIL. PARAÍBA: Soledade, 19.IV.2006, fl. e fr., M.F.A. Lucena 201 (PEUFR). PERNAMBUCO: Mirandiba, estrada para fazenda Troncão, 16.IV.2007, fl. e fr.,
J.S. Silva et al. 161 (UFP). PIAUÍ: Cajueiro da Praia, margem da estrada, 11.III.2006, fl., F. Soares Filho 439 (UFP).

Croton blanchetianus é exclusivamente brasileira (Alagoas, Bahia, Ceará, Minas Gerais, Paraíba, Pernambuco, Piauí, Rio Grande do Norte, Sergipe), ocorrendo em vegetação de carrasco (Ceará) e de caatinga (Gomes 2006). Em Pernambuco, pode ocorrer ainda nas bordas das florestas serranas (Gomes 2006). No Vale do Ipanema, foi observada apenas no município de Águas Belas, em vegetação de caatinga sobre solos arenosos, com flores em junho.

As folhas curtamente palmatinérvias, as estípulas foliáceas, geralmente auriculadoreniformes, o disco segmentado nas flores estaminadas, os estiletes unidos em coluna e a cápsula oblata transversalmente trilobada a distinguem das demais espécies. É amplamente conhecida por marmeleiro ou velame.

4. Croton corchoropsis Baill., Adansonia 4: 364. 1864.

Fig. 3a-h

Subarbustos a arbustos, 0,5-2,5 m alt., monóicos, látex incolor. Indumento tomentoso; tricomas estrelados, sésseis a curtamente estipitados, amarelados. Ramos castanhos. Folhas alternas, às vezes opostas; estípulas não foliáceas, sem glândulas, cedo caducas; pecíolos 0,4-1 cm compr., não viscosos, sem glândulas; lâmina 1,5-3,3×0,5-1 cm, cartácea, concolor, elíptica, base redonda, ápice agudo, margem inteira, puberulento-tomentosa, nervação hifódroma. Inflorescência 1-2 cm compr., solitária, racemiforme, sem espaço estéril entre as címulas de flores estaminadas e de flores pistiladas; brácteas $0,3-0,5 \times 0,2-$ $0,3 \mathrm{~mm}$, inteiras, lanceolado-ovais, glândulas punctiformes translúcidas acobreadas. Flores estaminadas 1,5-2,3 mm compr.; pedicelo 12,8 mm compr.; sépalas 5, 1-1,5×0,6-0,7 mm, valvares, elípticas a ovais, externamente tomentosas, internamente glabras, sem glândulas; pétalas 5,1-2 ×0,4-0,6 mm, oblanceoladas, ciliadas, externamente glabras, internamente vilosas, às vezes com glândulas punctiformes translúcidas acobreadas; estames 10 ou 11, 1,5-3 mm compr., filetes glabros; receptáculo viloso; disco inteiro, 
pentalobado, lobos oblongos, glabros. Flores pistiladas 2-3 mm compr.; pedicelo $3-7 \mathrm{~mm}$ compr.; sépalas 5, 2-3×0,8-1 mm, valvares, não reduplicadas, iguais entre si, lanceoladas a elípticas, unidas por $1 / 4$ de seu comprimento, externamente tomentosas, internamente tomentosavilosas, sem glândulas; pétalas 5, filiformes; ovário 1,6-3 × 1,5-2,8 mm, orbicular, tomentoso; estilete multífidos, livres, ascendentes; disco inteiro, petalobado, lobos oblongos, glândulas punctiformes translúcidas acobreadas esparsas. Cápsula 4-7×3-4 mm, elipsóide, esverdeada, tomentosa; columela com ápice inteiro após a deiscência do fruto. Sementes 2-6×ca. 3,4 mm, elipsóides, rugosas, marrons.

Material selecionado: Buíque: Catimbau, 18.X.1994, fl. e fr., M.F.A. Lucena et al. 5 (PEUFR); Chapada de São José, 3.IV.2000, fl., M.F. Sales 1060 (IPA); estrada Buíque - Catimbau, 4.IX.1995, fl. e fr., A. Laurênio \& A.P.S. Gomes 123 (PEUFR); Paraíso Selvagem, 17.VIII.1995, fl., L. Figueirêdo \& W. Andrade 157 (PEUFR); Serra de Jerusalém, 14.II.2008, fl. e fr., J.S. Silva et al. 403 (PEUFR).

Croton corchoropsis ocorre em áreas secas das Regiões Centro-Oeste (Goiás), Norte (Tocantins), Nordeste (Bahia, Maranhão e Pernambuco) e Sudeste (Minas Gerais e São Paulo). Na área de estudo, está associada a ambientes rupestres, crescendo frequentemente em fendas de rocha, em altitudes acima de $800 \mathrm{~m}$, florindo e frutificando de fevereiro a outubro. Caracteriza-se por apresentar tricomas estrelados, estrelado-lepidotos sésseis a curtamente estipitados, folhas de margem inteira, nervação hifódroma, ausência de glândulas no pecíolo, flores pistiladas na base, bem distanciadas entre si, flores estaminadas aglomeradas na porção distal, 10 ou 11 estames e estiletes multífidos. Vegetativamente é bastante semelhante a $C$. pedicellatus Kunth, sendo muitas vezes difícil distingui-las, tanto que Caruzo \& Cordeiro (2007) as consideraram sinônimo. Paul Berry e Benjamin van Ee (comunicação pesssoal), no entanto, acreditam se tratarem de espécies distintas e que $C$. pedicellatus, descrita para o Peru, provavelmente não ocorra no Brasil. Depois de analisar a fotografia dos holótipos, o protólogo das duas espécies e verificar a distância entre as localidades tipo, concordamos com a posição destes pesquisadores. Ainda assim, elas devem fazer parte de um complexo de espécies afins e necessitam de estudos mais aprofundados.

\section{Croton echioides Baill., Adansonia 4: 334.} 1864.

Fig. 3i-1

Arbustos, 1-1,5 $\mathrm{m}$ alt., monóicos, látex incolor ou vermelho após exudado. Indumento tomentoso; tricomas estrelado-rotados e estreladoporrectos esbranquiçados a ferrugíneos. Ramos acinzentados. Folhas alternas; estípulas 1-3,3 $\times 0,3-0,7 \mathrm{~mm}$, persistentes, não foliáceas, estreitamente triangulares, sem glândulas; pecíolos 1-4 cm compr., não viscosos; glândulas 2-4, 0,4-1 mm diâm., basilaminares, sésseis a curtamente estipitadas, discóides; lâmina 3-10 $\times$ 2,5-7 cm, cartácea, discolor, elíptica, base cordada, ápice agudo, margem inteira, às vezes, glandular, face superior verde, puberulenta pubescente, face inferior esbranquiçada, tomentosa a serícea; nervação eucamptódroma. Inflorescência 5-13 cm compr., solitária, racemiforme, sem espaço estéril entre as címulas de flores estaminadas e de flores pistiladas, címulas com 2 ou 3 flores; brácteas $0,5-1,2 \times 0,3-0,7 \mathrm{~mm}$, 1-3 por címula, inteiras, ovais, sem glândulas. Flores estaminadas 3-4 mm compr.; pedicelo 1-3 mm compr.; sépalas 5, 1,7-2,3 ×0,8-1 mm, valvares, ovais, externamente pubescentes, internamente glabrescentes, sem glândulas; pétalas $5,1,8-2,2 \times 0,6-0,8 \mathrm{~mm}$, valvares, oblanceoladas, não ciliadas, externamente glabras, internamente vilosas, sem glândulas; estames 1517,2,4-4 mm compr., filetes glabros, receptáculo viloso; disco com 5 glândulas, transversalmente elipsóides, glabras. Flores pistiladas $2-3 \mathrm{~mm}$ compr., sésseis; sépalas 5, 1,2-2,5×1-1,2 mm, valvares, não reduplicadas, iguais entre si, elípticas a ovais, unidas por $1 / 4$ do seu comprimento, externamente pubescentes a ligeiramentes vilosas, internamente seríceas a glabrescentes, sem glândulas; pétalas 5, inconspícuas, filiformes; ovário 1,5-3×1,5-2,5 mm, orbicular, hirsuto; estiletes 2-fidos, livres, patentes; disco inteiro, pentalobado, lobos oblongos, glabros. Cápsula 4-5 × ca. 0,4 mm, oblata, verde, puberulenta; columela com ápice inteiro após 


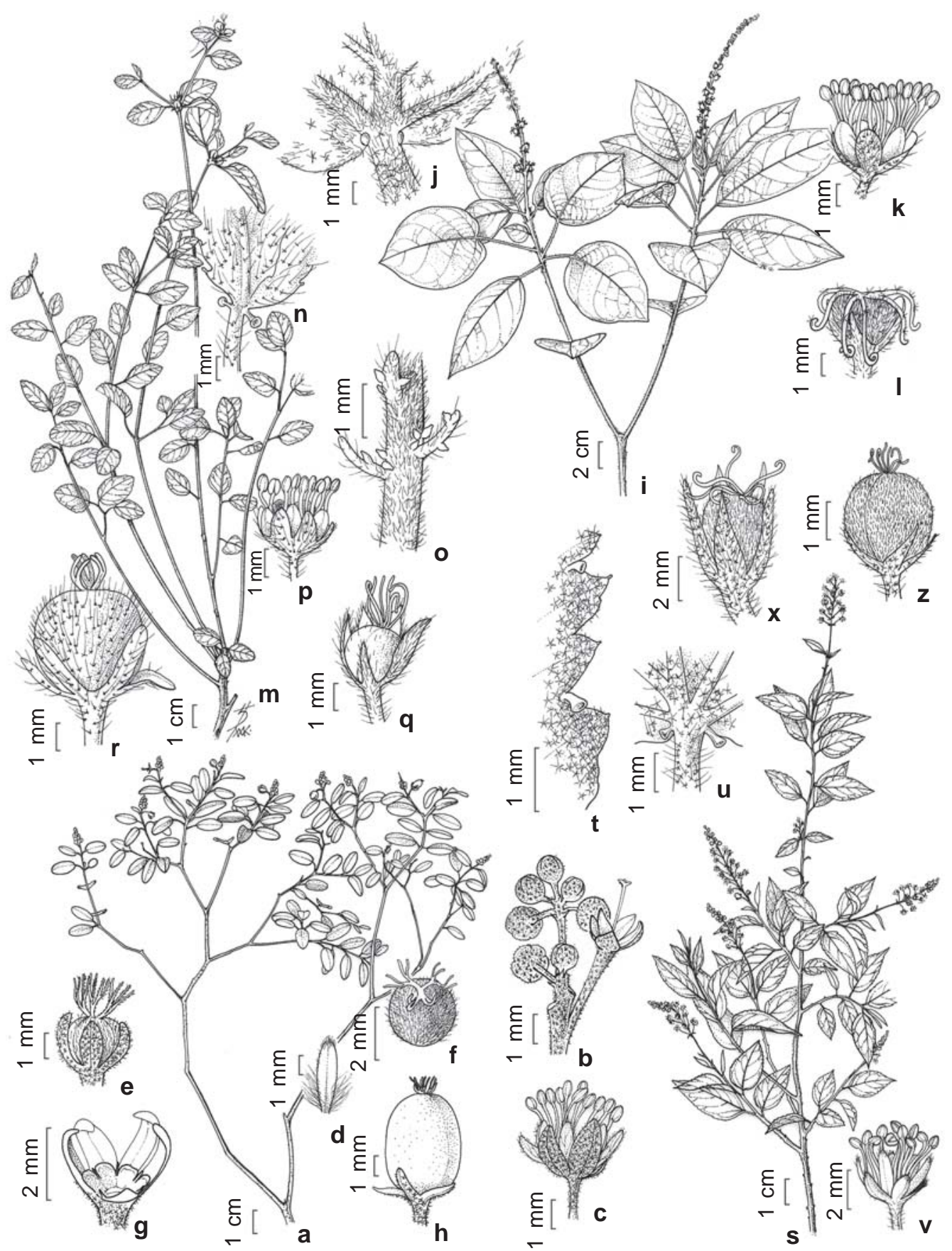

Figura 3 - a-h. Croton corchoropsis - a. ramo; b. inflorescência; c. flor estaminada; d. pétala da flor estaminada; e. flor pistilada; f. detalhe do gineceu evidenciando os estiletes; g. disco da flor pistilada; h. fruto (A. Laurênio \& A.P.S.Gomes 123). i-1. Croton echioides - i. ramo; j. glândulas basilaminares; k. flor estaminada; l. flor pistilada (A. Laurênio \& A.P.S. Gomes 2007). m-r. Croton glandulosus - m. ramo; n. glândulas acropeciolares; o. detalhe das glândulas nas brácteas; p. flor estaminada; q. flor pistilada; r. fruto (E.P. Heringer et al. 119). s-z. Croton grewioides - s. ramo; t. detalhe das glândulas entre os dentes da margem do limbo; u. glândulas acropeciolares; v. flor estaminada; x. flor pistilada; z. fruto (J.S. Silva et al. 413).

Figure 3 - a-h. Croton corchoropsis - a. branch; b. inflorescence; c. staminate flower; e. pistillate flower; f. gynoecium details showing the styles; g. disk of the pistillate flower; h. fruit (A. Laurênio \& A.P.S.Gomes 123). i-1. Croton echioides - i. branch; j. base of leaf blade with glands; k. staminate flower; 1. pistillate flower (A. Laurênio \& A.P.S. Gomes 2007). m-r. Croton glandulosus - m. branch; n. acropetiolar glands; o. glands details on bracts; p. staminate flower; q. pistillate flower; r. fruit (E.P. Heringer et al. 119). s-z. Croton grewioides - s. branch; t. leaf margin with marginal glands; u. acropetiolar glands; v. staminate flower; x. pistillate flower; z. fruit (J.S. Silva et al. 413). 
a deiscência do fruto. Sementes ca. $5 \times 2-3$ $\mathrm{mm}$, oblongas, rugosas, amarronzadas.

Material examinado: Buíque: fazenda Botija, 6.V.2003, fl., A.P.S. Gomes \& A. Laurênio 1106 (PEUFR); Paraíso Selvagem, 8.V.2003, fl. e fr., A. Laurênio 2035 (PEUFR); Serra do Catimbau, 6.V.2003, fr., A. Laurênio \& A.P.S. Gomes 2007 (PEUFR); Serra de Jerusalém, 14.II.2008, fl., J.S. Silva et al. 402 (PEUFR); trilha Caiana, 5.VIII.2006, fl., M.F.A. Lucena et al. 1692 (UFP).

Croton echioides está restrita ao semiárido brasileiro, crescendo em vegetação de caantiga (Alagoas, Bahia, Ceará, Minas Gerais, Paraíba, Pernambuco, Piauí, Rio Grande do Norte), cerrado (Piauí) e em áreas transicionais de caatinga-cerrado (Piauí). Na área de estudo, ocorre nas caatingas, sobre sedimentos arenosos e em formações rupestres, em altitudes que variam de 400 a $800 \mathrm{~m}$.

É bem diferenciada das demais espécies por ser a única que possui flores pistiladas sésseis e estiletes patentes, ultrapassando o comprimento do ovário. Foi encontrada com flores em fevereiro, maio e agosto e com frutos em maio.

6. Croton glandulosus L., Syst. nat. (ed. 10) 2: 1275.1759.

Fig. 3m-r

Subarbustos, 0,2-0,5 m alt., monóicos, látex ausente. Indumento tomentoso; tricomas estrelado-porrectos e raramente fasciculados, esbranquiçados. Ramos esverdeados a marrons. Folhas alternas, às vezes verticiladas próximas às bifurcações dos ramos; estípulas 1-2,5 × ca. 0,2 mm, persistentes, não foliáceas, lineares, sem glândulas; pecíolos 0,4-3,2 cm compr., não viscosos; glândulas 2, 0,4-0,7 mm diâm., acropeciolares, estipitadas, discóides; lâmina 1,3-6,3×1,6-2,7 cm, membranácea, concolor, oval-elíptica, base arredondada, ápice agudo, margem serreada a denteado-glandular, face superior pubescente, face inferior serícea; nervação eucamptódroma. Inflorescência 0,8 2 cm compr., solitária, racemiforme, sem espaço estéril entre as címulas de flores estaminadas e de flores pistiladas; brácteas 1-1,5×ca. 0,2 mm, inteiras, lineares, com 4-6 glândulas, piriformes, sésseis. Flores estaminadas 1,2-2 mm compr; pedicelo 1,2-2 mm compr.; sépalas 5, 1,2-2× $0,5-0,6 \mathrm{~mm}$, valvares, ovais, externamente vilosas, internamente glabras, sem glândulas; pétalas 5, 1,2-2 ×0,3-0,4 mm, oblanceoladas, ciliadas, externamente glabras, internamente vilosas, sem glândulas; estames 8-10, 1,8-2 mm compr., glabros, receptáculo viloso; disco com 5 glândulas, ovóides, glabras. Flores pistiladas 2,4-3 mm compr.; pedicelo 0,8-1 mm compr.; sépalas $5,2-2,7 \times 0,6-1 \mathrm{~mm}$, valvares, no reduplicadas, desiguais entre si, 3 lineares, 2 lanceoladas, unidas por $1 / 4$ de seu comprimento, externamente vilosas, internamente glabras com glândulas quadrangulares na base, às vezes com glândulas punctiformes translúcidas esparsas; pétalas 5, inconspícuas, filiformes; ovário 1-1,2 $\times 1-1,2$ mm, obovóide, lanoso-viloso; estiletes 2-fidos, livres, ascendentes; disco inteiro, discóide, glabro. Cápsula 3,5-5 × 3-5 mm, orbicular, esverdeada, vilosa; columela com ápice inteiro após a deiscência do fruto. Sementes 2,5-4× ca. $2 \mathrm{~mm}$, elipsóide-orbiculares, discretamente rugosas, creme a marrom-claras.

Material selecionado: Buíque: Catimbau, 4.IX.2007, fl. e fr, J.S. Silva \& L. Lima 267 (PEUFR); Serra Branca, 20.XII.1997, fl. e fr., M.F.A. Lucena et al. 395 (PEUFR); Serra do Catimbau, 19.VI.1994, fl. e fr., A.M. Miranda et al. 1834 (PEUFR). Pedra: Reserva da Igreja Católica, 2.VII.2006, fl. e fr., J.S. Silva et al. 220 a (PEUFR).

Está amplamente distribuída na região neotropical, nos Estados Unidos, México e América Tropical (Govaerts et al. 2000). No Brasil, ocorre da Amazônia até o Rio Grande do Sul, em diferentes ambientes: cerrado, caatinga, brejos de altitudes (Pernambuco), matas de tabuleiros, restingas, pantanal e floresta atlântica (Lucena 2001). No Vale do Ipanema, cresce em vegetação de caatinga e em áreas antropizadas, sobre solos arenoargilosos, alaranjados, tendo sido encontrada com flores em junho, setembro e dezembro e com frutos em junho e julho.

Croton glandulosus é morfologicamente semelhante a $C$. hirtus por apresentarem o hábito subarbustivo, margem das folhas denteada, glândulas acropeciolares, brácteas glandulares, sépalas das flores pistiladas desiguais e estiletes 2-fidos, por isso são frequentemente confundidas. Distingue-se 
daquela espécie principalmente pelas glândulas sésseis das brácteas e o número de estames variando de 8 a 10.

7. Croton grewioides Baill., Adansonia 4: 365. 1864.

Fig. $3 \mathrm{~s}-\mathrm{z}$

Arbustos, 0,7-2 m alt., monóicos, com forte aroma de canela perceptível até em material herborizado, látex ausente. Indumento glabrescente a tomentoso; tricomas estreladoporrectos amarelados, às vezes ferrugíneos, raramente dendríticos ou multi-radiado-porrectos. Ramos acinzentados. Folhas alternas; estípulas ca. $1 \times 0,2 \mathrm{~mm}$, caducas, nãofoliáceas, estreitamente oblongas, sem glândulas; pecíolos $0,5-1 \mathrm{~cm}$ compr., não viscosos; glândulas 2, 0,3-1 mm diâm., acropeciolares, estipitadas, pateliformes; lâmina 1,1-3,6 ×0,6-2,4cm, membranácea, concolor, elíptica, base arrredonda, ápice agudo, margem bisseriado-glandular, glândulas piriformes no ápice dos dentes, estipitadas, pateliformes entre os dentes, face superior puberulenta, face inferior puberulenta a tomentosa; nervação eucamptódroma. Inflorescência 1,3-5 cm compr., solitária, racemiforme, sem espaço estéril entre as címulas de flores estaminadas e de flores pistiladas; brácteas $0,6-1,2 \times 0,2-0,4 \mathrm{~mm}$, inteiras, estreitamente oblongas, sem glândulas. Flores estaminadas 2-3 mm compr.; pedicelo 1-3 mm compr.; sépalas 5, 1-2×0,5-0,8 mm, valvares, ovais, externamente pubescentes, internamente glabras, glândulas punctiformes translúcidas douradas; pétalas $5,1-2 \times 0,4-0,5$ $\mathrm{mm}$, valvares, oblanceoladas, ciliadas, externamente pubescentes, internamente vilosas, glândulas punctiformes translúcidas douradas; estames 11,2-2,4 mm compr., filetes vilosos, receptáculo viloso; disco inteiro, pentalobado, lobos transversalmente elipsóides, glabros. Flores pistiladas 3-4 mm compr.; pedicelo 2-3 $\mathrm{mm}$ compr.; sépalas 5, 2-3×0,4-1 mm, valvares, não reduplicadas, iguais entre si, lanceoladas, unidas por ca. $1 / 4$ de seu comprimento, externamente pubescente-tomentosas, internamente glabras, glândulas punctiformes translúcidas douradas; pétalas ausentes; ovário 2-2,3 × 2-2,3 mm, orbicular, velutino; estiletes 2 -fidos, livres, patentes; disco inteiro, discretamente pentalobado, lobos oblongos, glabros. Cápsula 4-5×3-4 mm, orbicular, castanha, pubescente-tomentosa; columela com ápice inteiro após a deiscência do fruto. Sementes $2,5-3 \times 2,4-2,8 \mathrm{~mm}$, orbiculares, lisas, marrons.

Material selecionado: Buíque: Estrada do Fortuoso, 11.II.2008, fl., J.S. Silva et al. 372 (PEUFR); Paraíso Selvagem, 14.II.2008, fl., J.S. Silva et al. 413 (PEUFR); Serra de Jerusalém, 14.II.2008, fl., J.S. Silva et al. 408 (PEUFR); sítio Pititi, 10.IV.1997, fr., A. Laurênio et al. 445 (PEUFR); Serra do Catimbau, 08.III.1996, fl. e fr., M. Tschá et al. 652 (PEUFR). Pedra: 30.III.1991, fl., J. Coelho s.n (IPA 52559).

Está restrita ao semi-árido brasileiro, ocorrendo em Alagoas, Bahia, Ceará, Minas Gerais, Paraíba, Pernambuco, Piauí, Rio Grande do Norte e Sergipe, frequentemente entre rochas, em solos arenosos (Carneiro-Torres 2009). Na área de estudo, está mais associada a locais com altitudes elevadas, de 600 a 800 metros, onde cresce em caatinga, sobre sedimentos arenosos e campo rupestre. Apresenta floração em fevereiro e março e frutificação em abril e maio.

Pode ser reconhecida pelo porte arbustivo, glândulas acropeciolares, estipitadas e pateliformes e sépalas de ambos os sexos revestidas por glândulas punctiformes translúcidas. Outro caráter peculiar de Croton grewioides são suas inflorescências alongadas $(1,3-5 \mathrm{~cm}$ compr.), vistosas, portando flores aromáticas, muito visitadas por abelhas. Em algumas regiões do Nordeste (Piauí), o mel de suas flores é muito apreciado devido ao seu gosto e aroma característicos de canela. Éconhecida popularmente como canelinha ou canelinha-de-cheiro em alusão ao aroma exalado pelas folhas.

\section{Croton heliotropiifolius Kunth in} Humboldt, Bonpland \& Kunth, Nov. gen. sp. (quarto ed.) 2: 83. 1817.

Fig. 4a-d

Arbustos, 0,7-2,5 m alt., monóicos, látex incolor ou laranja após exudado. Indumento tomentoso; tricomas estrelado-porrectos, esbranquiçados a dourado. Ramos verdeacinzentados. Folhas alternas a subopostas no ápice dos ramos; estípulas 1,4-1,8×ca. 0,3 mm, persistentes, não foliáceas, elípticas, sem glândulas; pecíolos $0,5-1,5 \mathrm{~cm}$ compr., não viscosos, 
geralmente sem glândulas; quando presentes, 2 glândulas inconspícuas, 0,2-0,3 mm diâm., acropeciolares, sésseis, globosas; lâmina 2-10 $\times 0,7-5 \mathrm{~cm}$, membranácea-cartácea, concolor, lanceolada a oval, base discretamente cordada, ápice agudo, margem inteira a esparsamente serrilhada, às vezes glandular, face superior pubescente-puberulenta, face inferior tomentosa; nervação eucamptódroma. Inflorescência 2,6$6,5 \mathrm{~cm}$ compr., solitária, racemiforme, sem espaço estéril entre as címulas de flores estaminadas e de flores pistiladas; címulas estaminadas com 2 ou 3 flores, flores pistiladas solitárias; brácteas $0,8-1,2 \times 0,3-0,4 \mathrm{~mm}, 1$ ou 2 por címulas, inteiras, lanceoladas, sem glândulas. Flores estaminadas 1,8-3 mm compr.; pedicelo 2-4 mm compr.; sépalas 5, 1,8-2,5×1 mm, elípticas, externamente vilosas, internamente glabras, sem glândulas; pétalas 5, 1,8-3, ×0,6-1 mm, oblanceoladas, não ciliadas, externamente glabras, internamente vilosas, sem glândulas; estames 14 21,2,5-3 mm compr., filetes glabros, receptáculo viloso; disco com 5 glândulas, oblongas, glabras. Flores pistiladas 5-6 mm compr., curtamente pediceladas ou sésseis; pedicelo 1-3 mm compr., sépalas 5, 1,8-2 ×0,3-0,5 mm, valvares, não reduplicadas, iguais entre si, lanceoladas, unidas por $1 / 4$ de seu comprimento, externamente vilosas, internamente pubescentes, sem glândulas; pétalas ausentes; ovário 1-2 × 1-2 mm, orbicular, viloso; estiletes 2 -fidos, livres, ascendentes ou patentes; disco pentalobado, lobos ligeiramente truncados, glabros. Cápsula 5-7 × 3-5 mm, oblongo-elipsóide, castanha, vilosa; columela com ápice tripartido após a deiscência do fruto. Sementes 4-4,5 × ca. $2 \mathrm{~mm}$, elipsóides, lisas, castanhas. Material selecionado: Águas Belas: sítio Garcia, 10.I.1978, fl., G. Eloy 4 (UFP). Buíque: Chapada do São José, Alto da Palma, 8.V.2003, fl. e fr., A. Laurênio \& A.P.S. Gomes 2049 (PEUFR); Paraíso Selvagem, 17.IX.2007, fl., J.S. Silva \& J.S. Santos 293 (PEUFR). Pedra: margem do açude, 4.IX.2007, fl., J.S. Silva \& L. Lima 265 (PEUFR); Tupanatinga, Baião Grande, 12.IX.2000, fl., Callado 34 (IPA). Venturosa: Parque da Pedra Furada, 3.IX.2007, fl., J.S. Silva \& L. Lima 250, 251 (PEUFR).

Trata-se de uma espécie amplamente distribuída na região neotropical (Carneiro-Torres
2009). No Brasil, sua presença é verificada em praticamente toda Região Nordeste, estendendose até o estado de Minas Gerais (Lucena 2001). É encontrada, frequentemente, em vegetação de caatinga, embora também ocorra em brejos de altitude (florestas montanas), restingas e cerrados. $\mathrm{Na}$ área de estudo, destaca-se por estar amplamente distribuída, formando grandes populações em vegetação de caatinga, sobre solo arenoso ou areno-argiloso, onde foi encontrada com flores em maio, junho, julho e novembro e com frutos em maio e junho.

Ao longo de sua área de distribuição, $C$. heliotropiifolius apresenta grande variação morfológica quanto ao tamanho e forma das folhas, cor do indumento e comprimento das inflorescências, o que dificulta sua identificação. No entanto, pode ser diferenciada das demais espécies, principalmente, pela columela do fruto tripartida no ápice após a deiscência do fruto. Caracteriza-se, ainda, pelos tricomas estrelado-porrectos adensados nas estruturas vegetativas e reprodutivas. Além disso, geralmente não apresenta glândulas no pecíolo ou elas são inconspícuas e globosas, muitas vezes encobertas pelos tricomas.

9. Croton hirtus L' Hér., Stirp. nov.: 17, pl. 9. 1785. Fig. $4 \mathrm{e}-\mathrm{i}$

Subarbustos, 0,3-0,4 m alt., monóicos, látex ausente. Indumento hirsuto; tricomas estrelado-porrectos, dourados. Ramos amarelados. Folhas alternas a subopostas; estípulas 6-6,5×0,2-0,4 mm, persistentes, não foliáceas, lineares, sem glândulas; pecíolos 2,54,5 cm compr., não viscosos; glândulas 2, 1-2 $\mathrm{mm}$ diâm., acropeciolares, estipitadas, pateliformes; lâmina 3-10,5 × 2-7,5 cm, membranácea, oval, elíptica ou largamente oval, base arredondada, ápice agudo a obtuso, margem denteado-glandular, glândulas piriformes no ápice dos dentes, concolor, pubescente a hirsuto; nervação actinódroma. Inflorescência 2-4 cm compr., solitária, racemiforme, sem espaço estéril entre as címulas de flores estaminadas e de flores pistiladas; brácteas 2,5-3×0,3-0,4 mm, inteiras, lineares, com 2 ou 3 glândulas longamente estipitadas 


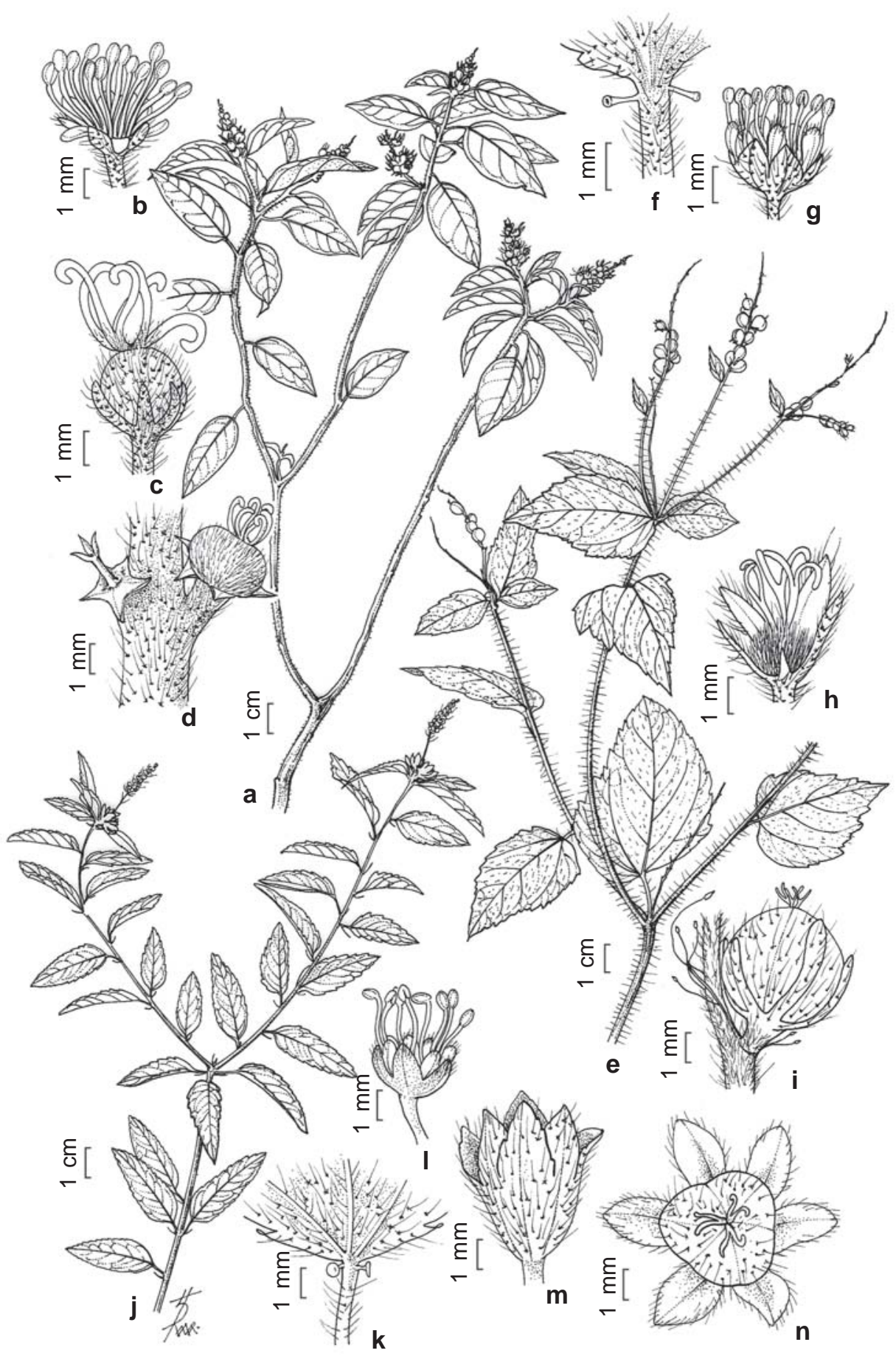

Figura 4 - a-d. Croton heliotropiifolius - a. ramo; b. flor estaminada; c. flor pistilada; d. fruto (W. Andrade et al. 306). e-i. Croton hirtus - e. ramo; f. glândulas acropeciolares; g. flor estaminada; h. flor pistilada; i. fruto (Carvalho Silva 206). j-n. Croton lundianus -j. ramo; k. glândulas acropeciolares; l. flor estaminada; m. flor pistilada; n. fruto (M.F. Sales et al. 497).

Figure 4 - a-d. Croton heliotropiifolius - a. branch; b. staminate flower; c. pistillate flower; d. fruit (W. Andrade et al. 306). e-i. Croton hirtus - e. branch; f. acropetiolar glands; g. staminate flower; h. pistillate flower; i. fruit (Carvalho Silva 206). j-n. Croton lundianus - j. branch; k. acropetiolar glands; 1 . staminate flower; m. pistillate flower; n. fruit (M.F. Sales et al. 497). 
(ca. $3 \mathrm{~mm}$ compr.), piriformes. Flores estaminadas 1-1,5 mm compr.; pedicelo $1-1,5 \mathrm{~mm}$ compr.; sépalas $5,1-1,5 \times$ ca. $0,5 \mathrm{~mm}$, valvares, ovais, externamente tomentosas a hirsutas, internamente glabras, sem glândulas; pétalas 5, 1-1,6- ×0,3$0,4 \mathrm{~mm}$, oblanceoladas, ciliadas, externamente glabras, internamente vilosas, glândulas punctiformes translúcidas acobreadas; estames 10 ou 11, 1,5$2 \mathrm{~mm}$ compr., filetes glabros, receptáculo viloso; disco com 5 glândulas, oblongas, glabras. Flores pistiladas 2-3 mm compr.; pedicelo 0,5$1 \mathrm{~mm}$ compr.; sépalas 5, 2,3-4 ×0,3-0,5 mm, valvares, não reduplicadas, desiguais entre si, 2 oblanceoladas, 3 filiformes, unidas por $1 / 4$ de seu comprimento, externamente hirsutas, internamente glabras, glândulas punctiformes translúcidas esparsas; pétalas ausentes; ovário ca. $1 \times 0,8-$ $1 \mathrm{~mm}$, orbicular, hirsuto; estiletes 2-fidos, livres, ascendentes; disco inteiro, discóide, glabro. Cápsula 4-4,5 ×3-3,5 mm, orbicular, castanha, hirsuta; columela comápice inteiro após a deiscência do fruto. Sementes 2,5-3×2-2,5 mm, oblongas, discretamente rugosas, castanhas.

Material examinado: Pedra: 28.VII.2006, fl., J.S. Silva et al. 206 (PEUFR).

Material adicional selecionado: BRASIL. BAHIA: Milagres, 16.III.1997, fr., F. França et al. 2167 (HUEFS). PERNAMBUCO: Agrestina, margem da BR-104, 8.IX.1998, fl.e fr., M.F.A. Lucena et al. 655 (PEUFR). PIAUÍ: Teresina, Parque Zoobotânico, 3.II.1999, fr., F. Santos Filho 9 (PEUFR). SERGIPE: Areia Branca, Serra da Itabaiana, 17.VI.2007, fl., B.S. Amorim et al. 125 (UFP).

Possui ampla distribuição na região neotropical, sendo registrada no Caribe e do México ao norte da Argentina (Govaerts et al. 2000). No Brasil, ocorre nas Regiões CentroOeste (Goiás), Nordeste (Bahia, Ceará, Maranhão, Pernambuco, Piauí, Rio Grande do Norte), Norte (Amazonas, Pará, Rondônia, Tocantins), Sudeste (Minas Gerais, São Paulo) e Sul (Santa Catarina, Paraná, Rio Grande do Sul), crescendo em cerrados, margem de matas ombrófilas e mesófilas e em área de pastos e plantações. No Vale do Ipanema, é encontrada em locais abertos, próximos às habitações, sobre solo areno-argiloso, tendo sido coletada com flores e frutos em julho.
Distingue-se das demais espécies, principalmente, pelo indumento hirsuto dos ramos, brácteas com glândulas piriformes longamente estipitadas, bem como pelas sépalas das flores pistiladas externamente hirsutas.

10. Croton lundianus (Didr.) Müll.Arg. in DC., Prodr. 15(2): 662. $1846 . \quad$ Fig. 4j-n

Ervas a subarbustos, 0,2-1 m alt., monóicos, látex incolor. Indumento tomentoso, às vezes hirsuto; tricomas estrelado-porrectos, raramente simples ou fasciculados, esbranquiçados a amarelados. Ramos esverdeados. Folhas alternas, às vezes opostas ou verticiladas no ápice dos ramos; estípulas 2,8-3,4 × 0,2-1,3 $\mathrm{mm}$, persistentes, não foliáceas, lineares, sem glândulas; pecíolos 0,3 2,5 cm compr., não viscosos; glândulas 2, 0,21,5 mm diâm., acropeciolares, estipitadas, discóides; lâmina 2,5-6×1-4 cm, membranácea, concolor, oval, base aguda a obtusa, ápice agudo, margem serreado-glandular, pubescente a tomentosa; nervação eucamptódroma. Inflorescência 1,7$4 \mathrm{~cm}$ compr., solitária, racemiforme, com espaço estéril entre as címulas de flores estaminadas e de flores pistiladas, exibindo a porção mediana da raque sem flores, címulas estaminadas com 1 ou 2 flores, címulas pistiladas com 2 ou 3 flores aglomeradas na porção inferior; brácteas 1,5-3 $\times 0,2-0,4 \mathrm{~mm}, 1$ por címula, inteiras, lineares, sem glândulas. Flores estaminadas 2,2-3 mm compr.; pedicelo 0,8-1,3 mm compr.; sépalas $5,1-2 \times 0,6-1 \mathrm{~mm}$, valvares, ovais, externamente puberulentas no ápice, internamente glabras, glândulas punctiformes translúcidas; pétalas $5,1,2-2 \times 0,4-0,8 \mathrm{~mm}$, elípticas a obovais, não ciliadas, externamente glabras, internamente vilosas na base, sem glândulas; estames 8-10, 2-3 mm compr., filetes glabros, receptáculo viloso; disco com 5 glândulas orbiculares, glabras. Flores pistiladas 5-8 mm compr.; pedicelo ca. 1 mm compr.; sépalas 6, 4-5×1,5-2 mm, valvares, não reduplicadas, iguais entre si, obovais, unidas por $1 / 4$ de seu comprimento, discretamente serreadas, externamente glabrescentes, internamente glabras, glândulas punctiformes translúcidas esparsas; pétalas 6, inconspícuas, lineares; ovário 1,5- 
2,7 $\times 1,5-2 \mathrm{~mm}$, orbicular, glabrescente a glabro; estiletes 2-fidos, livres, ascendentes; disco inteiro, pentalobado, lobos oblongos, glabros. Cápsula 3-3,4×3,8-4 mm, orbicular, castanha, glabrescente a glabra; columela com ápice inteiro após a deiscência do fruto. Sementes 3-3,3 × ca. 2,2 mm, elipsóides, discretamente rugosas, marrons.

Material examinado: Buíque: Vale do Catimbau, 28.VII.2005, fl., M.C. Abreu et al. 123 (PEUFR); Paraíso Selvagem, 12.II.2008, fl., J.S. Silva et al. 382 (PEUFR); 17.IX.2007, fl. e fr., J.S. Silva \& L. Lima 291 (PEUFR); Serra do Catimbau, 16.X.1970, fl. e fr., L. Xavier Filho 78 (UFP); trilha do Cemitério, 20.I.2006, fl. e fr, A.L. Bocage 1089 (IPA).

Croton lundianus é exclusiva da América do Sul, ocorrendo na Argentina, Brasil, Colômbia, Guiana Francesa e Paraguai. É considerada uma das espécies do gênero com maior área de distribuição no Brasil, sendo referida em praticamente todo território nacional (Cordeiro 1992). Ocorre geralmente em campos rupestres, caatingas, próximo a matas ciliares ou em capoeiras (Lima \& Pirani 2003). É pouco frequente na área de estudo, tendo sido observada apenas em Buíque, habitando solos arenosos, em vegetação arbustiva perenifólia. Floresce e frutifica o ano todo.

Distingui-se das demais espécies pelas inflorescências com descontinuidades entre as címulas estaminadas e pistiladas, exibindo a porção mediana da raque sem flores, pelas glândulas peciolares estipitadas, discóides e pelas sépalas das flores pistiladas em número de seis, discretamente serreadas.

11. Croton nummularius Baill., Adansonia 4: 360. 1864. Fig. 5a-i

Subarbustos, 0,4-0,6 m alt., monóicos, látex incolor. Indumento glabrescente a seríceo; tricomas estrelados e estreladoporrectos amarelados. Ramos acinzentados. Folhas alternas, conduplicadas quando secas; estípulas $0,5-1 \times 0,2-0,4 \mathrm{~mm}$, persistentes, não foliáceas, lanceoladas, laciniado-glandulares; pecíolos 1,4-4 mm compr., não viscosos, sem glândulas; lâmina $0,2-1 \times 0,3-1 \mathrm{~cm}$, cartácea, concolor, orbicular, base e ápice arredondado, margem denteado-glandular, glândulas sésseis, discóides, face superior glabrescente a glabra, face inferior puberulenta a glabrescente; nervação eucamptódroma. Inflorescência 0,8 2,2 cm compr., solitária, racemiforme, sem espaço estéril entre as címulas de flores estaminadas e de flores pistiladas; brácteas 0,4$1 \times 0,2-1 \mathrm{~mm}$, laciniado-glandulares, lanceoladas ou ovais. Flores estaminadas 1-2 mm compr.; pedicelo 1-4 mm compr.; sépalas $5,1-2,2 \times$ 0,9-1 mm, valvares, elípticas a ovais, externamente pubescentes a tomentosa, internamente glabras, glândulas punctiformes translúcidas douradas; pétalas 5, 1,7-2,2×0,7-1 mm, valvares, elípticas a obovais, não ciliadas, externamente puberulentas no ápice, internamente vilosas na base, glândulas punctiformes translúcidas douradas; estames 9-11, 1,3-3 mm compr., filetes pubescentes a vilosos, receptáculo viloso; disco com 5 glândulas, elipsóides, glabras. Flores pistiladas 2-3 mm compr.; pedicelo 1-3 mm compr.; sépalas 5, 2-3 ×0,6$1 \mathrm{~mm}$, valvares, não reduplicadas, iguais entre si, lanceoladas, unidas por ca. $1 / 4 \mathrm{de}$ seu comprimento, externamente pubescentes, internamente glabras, laciniado-glandulares; pétalas ausentes; ovário 1-1,5 × 1-1,5 mm, orbicular, tomentoso a seríceo; estiletes multífidos, livres, ascendentes; disco inteiro, pentalobado, lobos oblongos, glabros. Cápsula 2,5-4 × 2-3,5 mm, orbicular, amarronzada, puberulenta a tomentosa; columela com ápice inteiro após a deiscência do fruto. Sementes ca. $3 \times 1,8-2 \mathrm{~mm}$, oblongas, discretamente rugosas, castanhas.

Material selecionado: Buíque: fazenda Botija, 6.V.2003, fl. e fr., A. Laurênio \& A.P.S. Gomes 2008, 2012 (PEUFR); Paraíso Selvagem, 8.III.1996, fl. e fr., A. Laurênio et al. 351 (PEUFR); 8.V.2003, fl. e fr., A.P.S. Gomes \& A. Laurênio 2033, 2040 (PEUFR); Serra de Jerusalém, 14.II.2008, fl., J.S. Silva et al. 404 (PEUFR).

Trata-se de uma espécie disjunta das formações rupestres e campos gerais da Cadeia do Espinhaço (Bahia e Minas Gerais) e de Pernambuco (Carneiro-Torres 2009), crescendo em vegetação rupestre, em altitudes de 800 a $1.115 \mathrm{~m}$. No Vale do Ipanema, foi observada apenas nas áreas mais elevadas e planas do complexo da serra da Chapada de São José, 


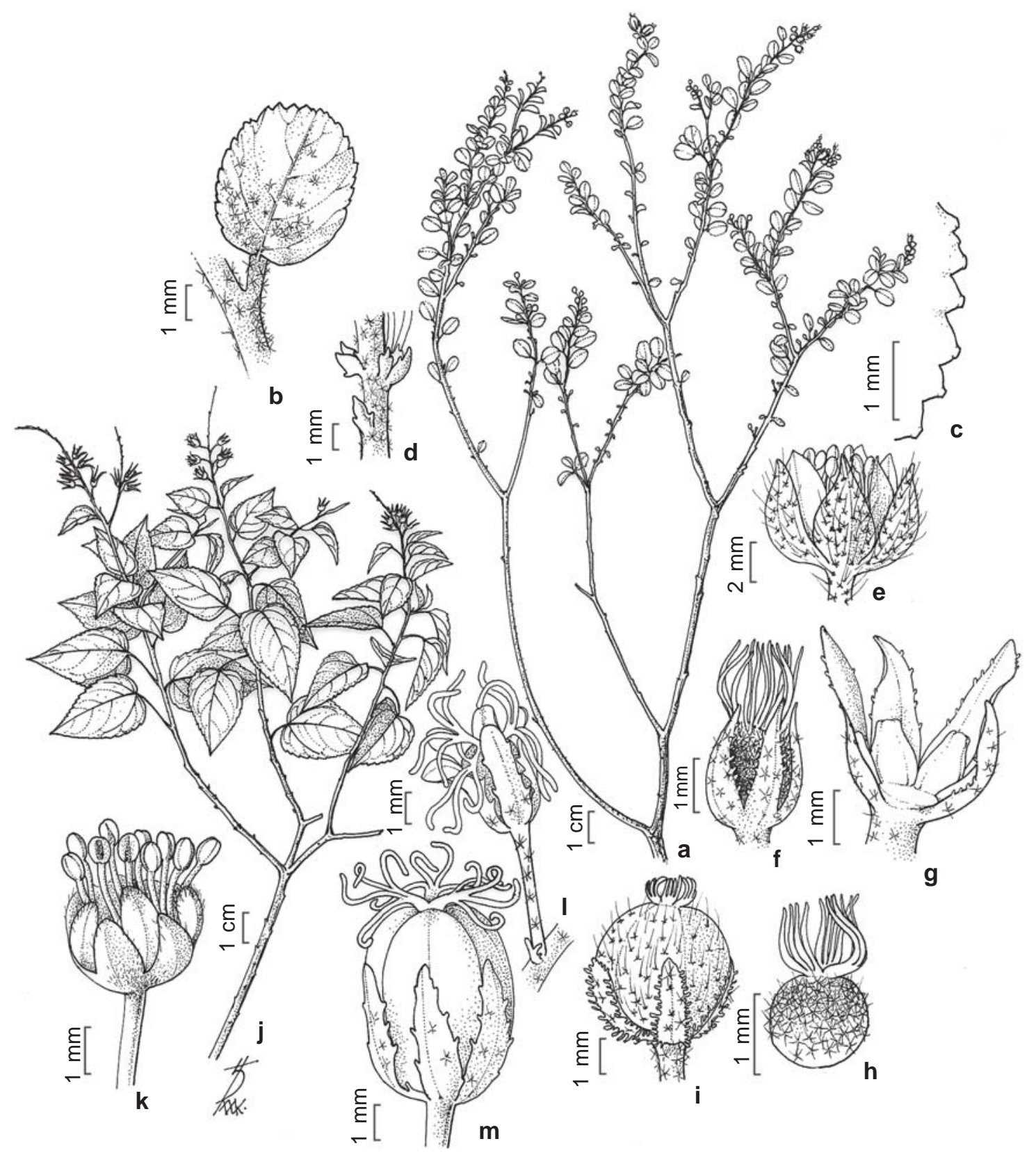

Figura 5 - a-i. Croton nummularius - a. ramo; b. folha; c. margem do limbo mostrando as glândulas; d. brácteas; e. flor estaminada; f. flor pistilada; g. disco da flor pistilada; h. gineceu; i. fruto (J.S. Silva et al. 404). j-m. Croton rudolphianus - j. ramo; k. flor estaminada; 1. flor pistilada; m. fruto (A.P.S. Gomes \& A. Laurênio 112).

Figure 5 - a-i. Croton nummularius - a. branch; b. leaf; c. leaf margin showing the glands; d. bracts; e. staminate flower; f. pistillate flower; g. disk of the pistillate flower; h. gynoecium; i. fruit (J.S. Silva et al. 404). j-m. Croton rudolphianus j. branch; k. staminate flower; 1. pistillate flower; m. fruit (A.P.S. Gomes \& A. Laurênio 112). 
em Buíque, crescendo a mais de 800 m de altitude, onde floresce e frutifica de fevereiro a maio.

Croton nummularius é um táxon bem delimitado. Distingui-se das demais espécies por apresentar folhas orbiculares, de margem denteado-glandular (glândulas discóides sésseis), além de pecíolo curto (1,4-4 mm compr.) e sépalas das flores pistiladas laciniadoglandulares. Em campo, pode ser reconhecida pelo caule bem ramificado, prostrado ou decumbente, e folhas pequenas $(0,2-1 \times 0,3-1 \mathrm{~cm})$, geralmente conduplicadas quando secas.

12. Croton rudolphianus Müll. Arg. in DC., Prodr. 15(2): 654. 1866. Fig. $5 \mathrm{j}-\mathrm{m}$

Arbustos, 0,8-1,5 m alt., monóicos, látex translúcido. Indumento glabrescente a viloso; tricomas estrelados, vináceo-enegrescidos. Ramos jovens viscosos, alaranjados. Folhas alternas, frequentemente dispostas no ápice dos ramos; estípulas $0,8-1,4 \times 0,4-1,2 \mathrm{~mm}$, persistentes, não foliáceas, lanceoladas, laciniado-glandulares; pecíolos 1-2,5 cm compr., viscosos, sem glândulas; lâmina 2-4,8 $\times 1,4-3 \mathrm{~cm}$, membranácea, concolor, oval a oval-elíptica, base cordada, ápice agudo, margem serreado-glandular, glândulas piriformes, face superior glabrescente a glabra, face inferior vilosa, glândulas punctiformes; nervação broquidódroma. Inflorescência 3,5$6 \mathrm{~cm}$ compr., solitária, racemiforme, sem espaço estéril entre as címulas de flores estaminadas e de flores pistiladas; brácteas $0,7-$ $1,5 \times 0,2-0,5 \mathrm{~mm}$, laciniado-glandulares, lanceoladas a estreitamente triangulares. Flores estaminadas 3-4 mm compr.; pedicelo 3-4 mm compr.; sépalas 5, 3-3,2 × 1,4-1,8 mm, valvares, ovais, glabrescentes, sem glândulas; pétalas 5, 3-3,2×1,4-2 mm, valvares, obovais, ciliadas, externamente glabras, internamente vilosas na base, sem glândulas; estames 10 , 4-5 mm compr., filetes pubescentes a vilosos, receptáculo pubescente; disco inteiro, pentalobado, lobos transversalmente elipsóides, glabros. Flores pistiladas 3-5 mm compr.; pedicelo 2-5 mm compr.; sépalas 5, 4-5×1$1,2 \mathrm{~mm}$, valvares, não reduplicadas, iguais entre si, oblongas a lanceoladas, unidas por $1 / 4$ de seu comprimento, glabrescentes, laciniadoglandulares; pétalas ausentes; ovário 1,5-3× 1,2-2 mm, elipsóide, glabrescente; estiletes multífidos, unidos na base, patentes; disco inteiro, pentalobado, lobos transversalmente elipsóides, glabros. Cápsula 4-6 × 3-4 mm, orbicular, amarronzada, glabra; columela com ápice inteiro após a deiscência do fruto. Sementes $3-3,5 \times 2-2,2 \mathrm{~mm}$, largamente elipsóides, discretamente rugosas, castanhas. Material selecionado: Buíque: Chapada de São José, 8.V.2003, fl., A.P.S. Gomes \& A. Laurênio 1124 (PEUFR); fazenda Botija, 6.V.2003, fl., A. Laurênio \& A.P.S. Gomes 2005 (PEUFR); Paraíso Selvagem, 14.II.2008, fl., J.S. Silva et al. 412 (PEUFR); Serra Branca, 12.II.2008, f1., J.S. Silva et al. 377 (PEUFR); trilha da Concha, 12.II.2008, fl., J.S. Silva et al. 381, 392 (PEUFR).

Croton rudolphianus ocorre em regiões de campo rupestre e de caatinga, nos estados de Alagoas, Bahia, Ceará, Minas Gerais e Pernambuco (Carneiro-Torres 2009). Na área de estudo, foi coletada apenas em Buíque, na Chapada de São José, crescendoem ambiente rupestre, apresentando flores de fevereiro a maio e frutos em maio.

Assemelha-se a $C$. urticifolius por compartilharem o hábito arbustivo, tricomas estrelados, folhas com base cordada, estípulas e brácteas glandulares e estiletes multífidos. Entretanto, difere daquela espécie por apresentar tricomas vináceo-enegrescidos, estípulas laciniado-glandulares, com glândulas obovóides densamente aglomeradas, pecíolo sem glândulas, inflorescências solitárias, sépalas das flores pistiladas glabrescentes, ovário glabrescente, estiletes patentes e cápsula glabra. Pode ser reconhecida no campo pelos ramos mais jovens alaranjados e viscosos; tal viscosidade pode estar relacionada à secreção de glândulas epidérmicas e sua função seria evitar a herbivoria (Martínez-Gordillo \& Matias 2005). É popularmente conhecida por velame-branco.

13. Croton tetradenius Baill., Adansonia 4: 343. 1864. Fig. 6a-g

Arbustos, 1-1,2 m alt., monóicos, aromáticos, látex translúcido. Indumento tomentoso a hirsuto-tomentoso; tricomas 
estrelado-porrectos, amarelados. Ramos castanhos. Folhas alternas a verticiladas no ápice dos ramos; estípulas $0,7-1 \times 0,3-0,4 \mathrm{~mm}$, persistentes, não foliáceas, triangulares, inteiras, sem glândulas; pecíolos $1-2,3 \mathrm{~cm}$ compr., não viscosos; glândulas 4-6, 1-1,2 mm compr., acropeciolares a basilaminares, estipitadas, cilíndricas; lâmina 5-7×2-3,5 cm, membranácea, concolor, oval, base arredondada, ápice agudo, margem inteira, às vezes glandular, face superior pubescente, face inferior pubescente-tomentosa; nervação eucamptódroma. Inflorescência 37,5 cm compr., solitária, racemiforme, sem espaço estéril entre as címulas de flores estaminadas e de flores pistiladas; brácteas $0,5-1,5 \times 0,4-1 \mathrm{~mm}$, inteiras, triangulares, sem glândulas. Flores estaminadas 2-3 mm compr.; pedicelo 1-1,2 mm compr.; sépalas 5, 1,5-2×1-1,2 mm, valvares, ovais, externamente pubescentes a tomentosas, internamente glabras, sem glândulas; pétalas 5, $1,5-2 \times 0,4-0,5 \mathrm{~mm}$, valvares, espatuladas, não ciliadas, externamente glabras a pubescentes no ápice, internamente vilosa na base, sem glândulas; estames 11-16, 1,5-2 mm compr., filetes glabros; receptáculo viloso; disco com 5 glândulas, oblongas, glabras. Flores pistiladas 2,8-3 mm compr.; pedicelo 1-2,3 mm compr.; sépalas 5, ca. $3 \times 1-1,3 \mathrm{~mm}$, valvares, não reduplicadas, iguais entre si, obovais, unidas por $1 / 4 \mathrm{de}$ seu comprimento, externamente tomentosas, internamente puberulentas no ápice, sem glândulas; pétalas 5, inconspícuas, oblongas a ovais; ovário ca. 1×1-2 mm, elipsóide, lanoso; estiletes 2-fidos, livres, ascendentes; disco inteiro, pentalobado, lobos oblongos a ovóides, glabros. Cápsula 3-5 × 2,5-3 mm, orbicular, castanha, tomentosa; columela com ápice inteiro após a deiscência do fruto. Sementes 3-4 × 2-3 mm, oblongas, rugosas, marrons.

Material examinado: Águas Belas: fazenda Nova, 29.XI.1969, fl., D. Andrade-Lima 5624 (IPA).

Material adicional examinado: PERNAMBUCO: Arcoverde, Estação Experimental do IPA, 22.III.1983, fl. e fr., F. Gallindo et al. 401 (IPA); Triunfo, 26.II.1986, fl. e fr., V.C. Lima 120 (IPA).

Croton tetradenius ocorre exclusivamente na Região Nordeste, tendo sido registrada para os estados de Alagoas, Bahia, Ceará, Paraíba, Pernambuco, Rio Grande do Norte e Sergipe
(Carneiro-Torres 2009). É encontrada, geralmente, em vegetação de caatinga e florestas perenifólias, sobre solo arenoso ou pedregoso, embora também ocorra com menos frequência em capoeiras, brejos de altitudes (Pernambuco) e áreas antropizadas. $\mathrm{Na}$ área de estudo, foi observada apenas no município de Águas Belas, crescendo em vegetação de caatinga, sobre solo argiloso com afloramentos rochosos, onde foi observada com flores e frutos em fevereiro e março.

A presença de 4-6 glândulas cilíndricas no pecíolo é a característica mais facilmente utilizada no seu reconhecimento. Aliados a esta característica, estão as sépalas das flores pistiladas obovais, externamente tomentosas, as pétalas das flores pistiladas inconspícuas oblongas a ovais e os estames em número de 11 a 16.

14. Croton urticifolius Lam., Encycl. 2: 213. 1786.

Fig. 6h-m

Arbustos, 1,5-2,5 m alt., monóicos, látex incolor. Indumento tomentoso; tricomas estrelados e estrelado-porrectos, esbranquiçados a amarelados. Ramos acinzentados. Folhas alternas a verticiladas no ápice dos ramos; estípulas $1-2 \times 0,4-1 \mathrm{~mm}$, persistentes, não foliáceas, elípticas, laciniado-glandulares; pecíolos 0,5-2,3 cm compr., não viscosos; glândulas 2-4, 0,4-1 mm compr., acropeciolares, subuladas; lâmina 2,5-6,4 × 1,4-3,9 cm, membranácea, concolor, oval a oval-elíptica, base cordada a arredondada, ápice agudo, margem serreada-glandular a crenado-glandular, glândulas globosas, face superior pubescente a tomentosa, face inferior tomentosa, às vezes com glândulas punctiformes translúcidas; nervação eucamptódroma. Inflorescência 6$22 \mathrm{~cm}$ compr., 1-4 dispostas no mesmo ponto, racemiforme, sem espaço estéril entre as címulas de flores estaminadas e de flores pistiladas; brácteas $1-1,5 \times 0,2-0,4 \mathrm{~mm}$, oblongas, laciniado-glandulares. Flores estaminadas 3 3,3 mm compr.; pedicelo 1-2 mm compr.; sépalas 5,2-2,5×1-1,5 mm, valvares, elípticas a ovais, glabras a pubescentes, glândulas punctiformes translúcidas douradas; pétalas 5, 2-3 × 1-1,5 mm, valvares, espatuladas, não 


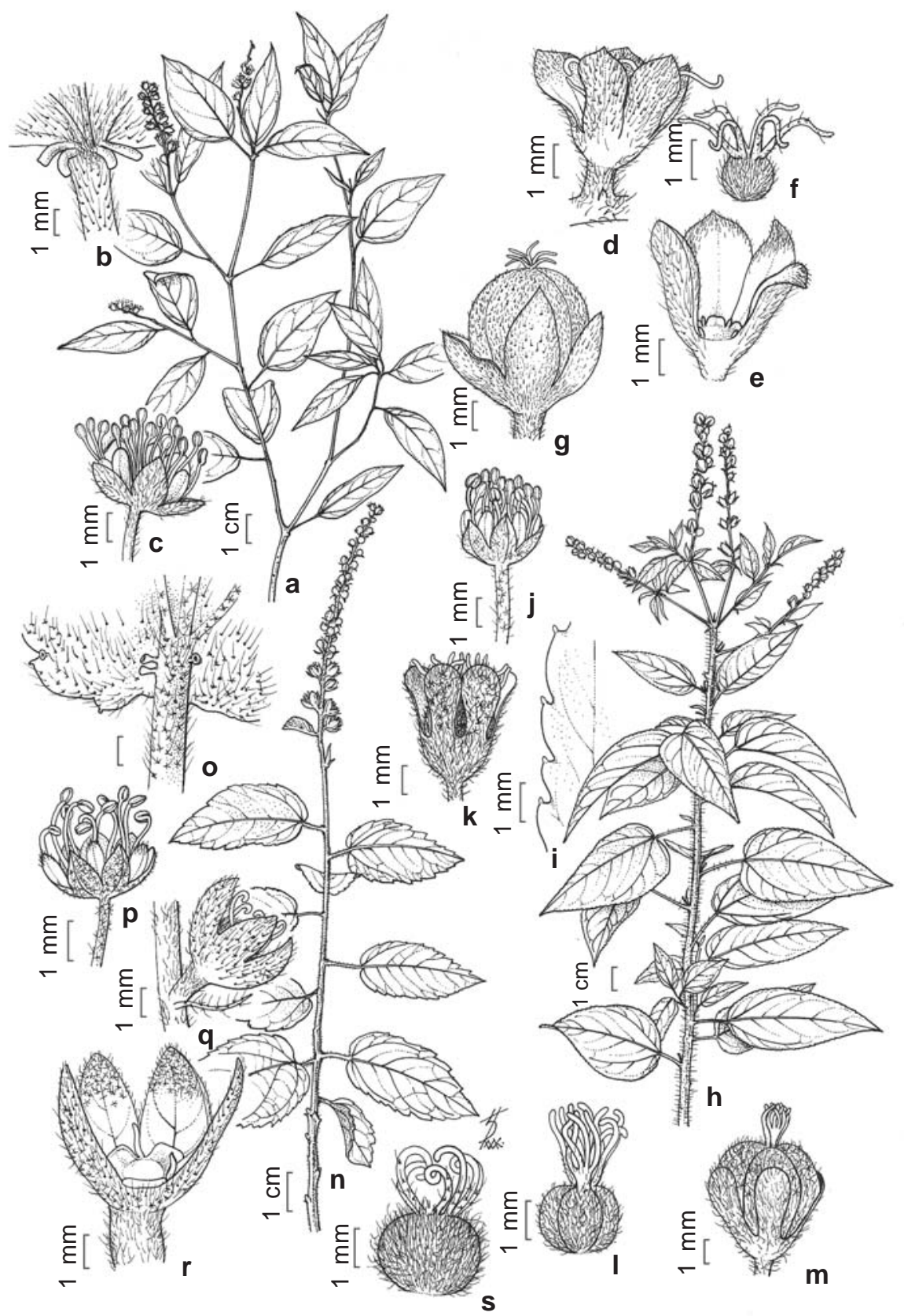

Figura 6 - a-g. Croton tetradenius - a. ramo; b. glândulas acropeciolares; c. flor estaminada; d. flor pistilada; e. disco da flor pistilada; f. gineceu; g. fruto (D. Andrade-Lima 5624). h-m. Croton urticifolius - h. ramo; i. margem do limbo mostrando as glândulas;. j. flor estaminada. k. flor pistilada; 1 gineceu; m. fruto (K. Costa 27). n-s. Croton virgultosus n. ramo; o. glândulas basilaminares; p. flor estaminada; q. flor pistilada; r. disco da flor pistilada; s. gineceu (J.S. Silva et al. 383).

Figure 6 - a-g. Croton tetradenius - a. branch; b. acropetiolar glands; c. staminate flower; d. pistillate flower; e. disk of the pistillate flower; f. gynoecium; g. fruit (D. Andrade-Lima 5624). h-m. Croton urticifolius - h. branch; i leaf margin showing the glands;. j. staminate flower. k. pistillate flower; 1. gynoecium; m. fruit (K. Costa 27). n-s. Croton virgultosus - n. branch; o. base of leaf blade with glands; p. staminate flower; q. pistillate flower; r. disk of the pistillate flower; s. gynoecium (J.S. Silva et al. 383). 
ciliadas, externamente glabras, internamente vilosas, glândulas punctiformes translúcidas douradas; estames 10-11, 1,8-3 mm compr., filetes vilosos a pubescentes; receptáculo glabro; disco inteiro, pentalobado, lobos obovóides, glabros. Flores pistiladas 5-6 mm compr.; pedicelo 1-2 mm compr.; sépalas 5, 3-6×2$2,2 \mathrm{~mm}$, valvares, não reduplicadas, iguais entre si, elípticas a obovais, unidas por $1 / 2$ a $1 / 3$ de seu comprimento, externamente tomentosas, internamente tomentosas; pétalas ausentes; ovário 1,5-2 × 1,2-2,3 mm, orbicular, tomentoso; estiletes multífidos, livres, ascendentes; disco inteiro, pentalobado, lobos tranversalmente elipsóides, glabros. Cápsula 4,5-5×4,5-5 mm, orbicular, amarronzada, tomentosa; columela com ápice inteiro após a deiscência do fruto. Sementes 2,5-4×2-2,2 mm, oblongas, rugosas, castanhas.

Material examinado: Buíque: 12.IX.2002, fl. e fr., K.P. Randau 16 (PEUFR). Pedra: Reserva da Igreja Católica, 2.VII.2006, fl. e fr., J.S. Silva et al. 280a (PEUFR). Venturosa: Parque da Pedra Furada, 21.III.1998, fl. e fr., K. Costa 27 (PEUFR).

É exclusiva da América do Sul, sendo registrada para Bolívia, Brasil, Guiana e Venezuela (Lucena 2001). No Brasil, ocorre nas Regiões Nordeste (Alagoas, Bahia, Ceará, Piauí, Pernambuco, Paraíba, Rio Grade do Norte e Sergipe), Norte (Amazonas e Pará) e Sudeste (Espírito Santo, Minas Gerais, Rio de Janeiro), em caatingas, florestas estacionais decíduais e campos rupestres (Carneiro-Torres 2009). No Vale do Ipanema, ocorre junto a afloramentos rochosos, sobre solo arenoso ou areno-argiloso, em caatinga, tendo sido encontrada com flores e frutos em março, julho e setembro.

Croton urticifolius é uma espécie que pode ser facilmente reconhecida pelas glândulas subuladas do pecíolo, inflorescências em número de 1 a 4 , dispostas em um mesmo ponto, sépalas e pétalas das flores estaminadas com glândulas punctiformes translúcidas douradas, sépalas das flores pistiladas externamente tomentosas, ovário tomentoso, estiletes ascendentes e cápsula tomentosa. Possui inflorescências vistosas, muito visitadas por abelhas, borboletas, mariposas, moscas e vespas.
15. Croton virgultosus Müll. Arg. in Martius \& Eichler, Fl. bras. 11(2): 104. 1873.

Fig. 6n-s

Arbustos, 0,8-1,3 m alt., monóicos, ligeiramente aromáticos, látex translúcido. Indumento tomentoso a viloso; tricomas estrelado-porrectos e dendríticos, esbranquiçados a ferrugíneos. Ramos cilíndricos, acinzentados. Folhas alternas; estípulas $2-9 \times 0,7-1 \mathrm{~mm}$, persistentes, não foliáceas, lineares, sem glândulas; pecíolos $0,5-1,3 \mathrm{~cm}$ compr., não viscosos; glândulas 2-4, 0,4-0,5 mm diâm., basilaminares, estipitadas, pateliformes; lâmina 2,5-6×1,3-4 cm, cartácea, concolor, oval, base cordada, ápice agudo, margem crenado-glandular com glândulas piriformes no ápice dos dentes e estipitados, pateliformes entre os dentes, face superior puberulenta, face inferior tomentosa; nervação eucamptódroma. Inflorescência 89,5 cm compr., solitária, espiciforme, sem espaço estéril entre as címulas de flores estaminadas e de flores pistiladas; címulas estaminadas com 1 ou 2 flores esparsas, flores pistiladas solitárias; brácteas $2-5 \times 0,2-0,3 \mathrm{~mm}, 1$ por címula, inteiras, lineares, sem glândulas. Flores estaminadas 3 $5 \mathrm{~mm}$ compr.; pedicelo 3-6 mm compr.; sépalas 5, 2-2,8 $\times 1-1,3 \mathrm{~mm}$, valvares, ovais, externamente vilosas, internamente glabras, sem glândulas; pétalas $5,2-3 \times 0,8-1 \mathrm{~mm}$, valvares, oblanceoladas, ciliadas, externamente pubescentes apenas na região distal, internamente vilosas, sem glândulas; estames 10 11, 3-4 mm compr., filetes glabros, receptáculo viloso; disco inteiro, pentalobado, lobos largamente ovóides, glabros. Flores pistiladas 3-5 mm compr.; pedicelo 1,5-2 mm compr.; sépalas 5, 2,4-5,6×0,8-3 mm, valvares, não reduplicadas, iguais entre si, elípticas a ovais, unidas por ca. $1 / 2$ de seu comprimento, externamente tomentosas a vilosas, internamente pubescentes a vilosas no ápice, sem glândulas; pétalas 5, inconspícuas, filiformes; ovário ca. 2 inteiro após a deiscência do fruto. Sementes não observadas.

Material examinado: Buíque: sítio Breu, 12.II.2008, fl., J.S. Silva et al. 391 (PEUFR); Serra do Catimbau, 15.III.2005, fl., R. A. Pick 159 (UFP).

Está restrita ao semi-árido brasileiro, ocorrendo na Bahia, Ceará, Pernambuco, Piauí e Rio Grande do Norte, em vegetação de caatinga 
e floresta estacional (Carneiro-Torres 2009). É pouco frequente na área de estudo, sendo coletada apenas em duas localidades de Buíque, em vegetação arbustiva, sobre solo arenoso, com flores em fevereiro e março.

Caracteriza-se pelo porte arbustivo, folhas com margem crenada, pecíolo com 2-4 glândulas estipitadas, pateliformes, inflorescências longas (8-9,5 cm compr.), sépalas das flores pistiladas elípticas a ovais e cápsula vilosa. Apresenta potencial melífero devido à grande quantidade de abelhas encontradas em suas flores.

\section{Agradecimentos}

Este trabalho é parte da dissertação de mestrado da primeira autora, realizada com o apoio do Conselho Nacional de Desenvolvimento Científico e Tecnológico (CNPq) e do Programa de Pós-Graduação em Botânica/UFRPE, instituições a quem agredecemos o apoio em todas as etapas. A Franck Silva, o auxilio nas ilustrações, aos curadores dos herbários citados o empréstimo e envio de material e aos dois assessores as sugestões.

\section{REFERÊNCIAS BIBLIOGRÁFICAS}

Andrade, K.V.S.A.; Rodal, M.J.N.; Lucena, M.F.A. \& Gomes, A.P.S. 2004. Composição florística de um trecho do Parque Nacional do Catimbau, Buíque, Pernambuco - Brasil. Hoehnea 31: 337-348.

Baillon, H. 1858. Etude génerale du grupo dés Euphorbiacées. Victor Masson, Paris.

Bentham, G. 1880. Note on Euphorbiaceae. Botanical Journal of the Linnean Society 37: 185-267.

Berry, P.E.; Hipp, A.L.; Wurdack, K.J.; Van Ee, B. \& Riina, R. 2005. Molecular phylogenetics of the giant genus Croton and tribe Crotoneae (Euphorbiaceae sensu stricto) using ITS and $\operatorname{trn} \mathrm{L}-\operatorname{trn} \mathrm{F}$ sequence data. American Journal of Botany 92: 1520-1534.

Carneiro-Torres, D.S. 2009. Diversidade de Croton L. (Euphorbiaceae) no bioma Caatinga. Tese Doutorado. Universidade Estadual de Feira de Santana, Feira de Santana. 387p.

Carneiro-Torres, D.S.; Cordeiro, I. \& França, F. 2002. A família Euphorbiaceae na flora de inselbergs da região de Milagres, Bahia, Brasil. Boletim de Botânica da Universidade de São Paulo 20: 31-47.

Caruzo, M.B.R. \& Cordeiro, I. 2007. Sinopse da tribo Crotoneae Dumort. (Euphorbiaceae s.s.) no estado de São Paulo, Brasil. Hoehnea 34: 571-585.

CPRM - Serviço Geológico do Brasil. 2005. Diagnóstico dos municípios de Águas Belas, Buíque, Itaíba, Pedra, Tupanatinga, Venturosa, estado de Pernambuco. In Mascarenhas, J. C. et al. (eds.). Projeto cadastro de fontes de abastecimento por água subterrânea. CPRM/ PRODEEM, Recife. 11p.

CONDEPE. 1993. Instituto de planejamento de Pernambuco - Perfil sócio-demográfico de Pernambuco. Governo do estado de Pernambuco, Recife. 61p.

Cordeiro, I. 1992. Flora da Serra do Cipó, Minas Gerais: Euphorbiaceae. Boletim de Botânica da Universidade de São Paulo 13: 169-217.

Cordeiro, I. 1995. Euphorbiaceae. In: Stannard, B.L. (ed.). Flora do Pico das Almas, Chapada Diamantina, Bahia-Brasil. Royal Botanic Gardens, Kew. Pp. 300-317.

Figueirêdo, L.S.; Rodal, M.J.N. \& Melo, A.L. 2000. Florística e fitossociologia da vegetação caducifólia espinhosa arbustiva no município de Buíque, Pernambuco. Naturalia 25: 205-224.

Gomes, A.P.S. 2006. Revisão das espécies sulamericanas de Croton L. subgen. Croton sect. Argyroglossum Baill. (CrotonoideaeEuphorbiaceae). Tese de Doutorado. Universidade Federal Rural de Pernambuco, Recife. 124p.

Gomes, A.P.S.; Rodal, M.J.N. \& Melo, A.L. 2006. Florística e fitogeografia da vegetação arbuistiva subcaducifólia da Chapada de São José, Buíque, PE, Brasil. Acta Botanica Brasilica 20:37-48.

Govaerts, R.; Frodin, D.G. \& Radcliffe-Smith, A. 2000. Croton. In: World checklist and bibliography of Euphorbiaceae (and Pandaceae.), vol. 2. Royal Botanic Gardens, Kew. Pp. 417-536.

Harris, J.G. \& Harris, M.W. 1994. Plant identification terminology. An illustrated glossary. 2 ed. Spring Lake Publishing, Spring Lake. 216p.

Lima, L.R. \& Pirani, J.R. 2003. O gênero Croton L. (Euphorbiaceae) na Cadeia do Espinhaço, Minas Gerais, Brasil. Boletim de Botânica da Universidade de São Paulo 21: 299-344.

Lima, L.R. \& Pirani, J.R. 2008. Revisão taxonômica de Croton sect. Lamprocroton (Müll. Arg.) Pax (Euphorbiaceae s.s). Biota Neotrópica 8: 177-231. 
Lucena, M.F. A. 2001. Estudos taxonômicos do gênero Croton L. (Crotonoideae-Euphorbiaceae) nas Zonas do Litoral e da Mata do estado de Pernambuco - Brasil. Dissertação de Mestrado. Universidade Federal Rural de Pernambuco, Recife. 136p.

Martínez-Gordillo, M. \& Matias, S.E. 2005.Tricomas foliares de Croton sección Barhamia (Euphorbiaceae). Acta Botanica Mexicana 72: 39-51.

Mueller, J. 1865. Euphorbiaceae. Linnaea 34: 77-142. Mueller, J. 1866. Croton. In Candolle, A. P. (ed.). Prodromus systematis naturalis regni vegetabilis, vol. 15. Victor Masson, Paris. Pp. 511-708.

Mueller, J. 1873. Croton. In Martius, C.F.P. \& Eichler, A.G. (eds.). Flora brasiliensis, vol 11. F. Fleischer, Lipsiae. Pp. 81-274.
Payo, H.A.; Dominicis, M.E.; Mayor, J.; Oquendo, M. \& Sarduy, R. 2001. Tamizaje fitoquímico preliminar de espécies del género Croton $\mathrm{L}$. Revista Cubana de Farmácia 35: 203-206.

Rizsk, A.F. 1987. The chemical constituents and economic plants of the Euphorbiaceae. Botanical Journal of the Linnean Society 94: 293-326.

Silva, J. S. \& Sales, M. F. 2008. O gênero Mimosa (Leguminosae-Mimosoideae) na microrregião do Vale do Ipanema, Pernambuco. Rodriguésia 59: 435-448.

Webster, G. L. 1993. A provisional synopsis of the section of the genus Croton (Euphorbiaceae). Taxon 42: 793-823.

\section{LISTA DE MATERIAL EXAMINADO}

Abreu, M. C. 123 (10); Alencar, M.E. 153 (5), 168 (5); Allem, A. 2905 (1), 2906 (1), 2995 (7), 3023 (3); Alves, M. 1114 (8), 1403 (11), 1404 (6), 1544 (7); Amorim, B. S. 125 (9); Andrade, W. 267 (2), 306 (8), 5624 (13); AndradeLima, D. 710 (7), 849 (14), 2228 (14), 5624 (13), 8058 (4); Araújo, E. 311 (3); Black, G. A. 11457 (14); Bocage, A. L. 1089 (10); Coelho, J. s/n (IPA 52559) (7); Colaço, M. 99 (1); Carneiro-Torres, D.S. 875 (1), 955 (1); Costa, K. 7 (2), 27 (14); Coradin, L. 6098 (11); Cordeiro, I. 656 (2); Costa, K. 27 (14), 109 (2); Costa e Silva, M. B. 2852 (14); Del'arco, M. s/n (7) (TEPB 707); Eloy, G. 4 (8); Emperaire, L. 527 (5); Figueirêdo, L. 5 (14), 157 (4), 363 (3); Fortius, G. 3761 (5); França, F. 2167 (9), 4080 (11); Gallindo, F. 401 (13); Gavilanes, M. L. 748 (6); Ginzbarg, S. 862 (6); Gomes, A.P.S. 15 (2), 112 (12), 509 (4), 1106 (5), 2005 (12), 2033 (11), 2040 (11); Grandi, T. S. M. s/n (BHCB 28100) (6); Harley, R. M. 6118 (5); Heringer, E. P. 119 (6), 211 (2), 846 (9), 880 (14), 993 (3); Irwin, H. S. 3178 (5), 3282 (11); Jardim, J. G. 3231 (5); Laurênio, A. 123 (4), 351 (11), 445 (7), 845 (8), 941 (6), 2007 (5), 2008 (11), 2035 (5), 2049 (8); Lima, V.C. 120 (13); Lima-Verde, L. W. 1354 (1), 1301 (14), 1314 (5); Locatelli, E. M. s/ n (UFP 39550) (3); Lucena, M.F.A. 5 (4); 10 (3), 201 (3), 395 (6), 528 (7), 655 (9), 703 (6), 1066 (1), 1199 (7), 1524 (9), 1692 (5), 1712 (7), 1723 (7), 1734 (9); Lucre, L. 4539 (14); Miranda, A. M. 1834 (6); Moura, D. 881 (1); Nascimento, L. 281 (8); Noblick, L. R. 2645 (6), 2657 (1), 3665 (2); Oliveira, M. 747 (9), 979 (9), 2311 (9), 2717 (3), 8883 (10); Orlandi, R. 377 (5); Pessoa, M. s.n (PEUFR 12420) (2); Pick, R. A. 159 (15); Pimentel, R. M. M. 93 (3); Queiroz, L.P. 301 (12), 1284 (12), 2602 (6), 5327 (11); Queiroz, R. T. 607 (1); Randau, K.P.9 (14), 16 (14), 19 (3), 20 (2), 21 (7); Rodal, M. J. N. 499 (12), 516 (14), 713 (2); Sales, M. F. 452 (8), 497 (10), 523 (12), 766 (12), 1060 (4); Santos s/n (UFP 39344) (3); Santos Filho, F.S. 9 (9), 423 (6), 439 (3); Scaramuzza, C. A. M. 670 (6); Sclindwein, C. 1127 (9); Silva, J. S. 161 (3), 206 (9), 220a, 250 (8), 251 (8), 265 (8), 267 (2), 270 (1), 280a (13), 291 (10), 293 (8), 371 (1), 372 (7), 377 (12), 381 (12), 383 (15), $386(1), 388$ (1), 391 (15), 392 (12), 397 (1), 399 (2), 400 (1), 402 (5), 403 (4), 404 (11), 407 (1), 408 (7), 412 (12), 413 (7), 498 (7); Soares Filho, F. 439 (3); Souza, V. C. 7057 (6); Tschá, M. 567 (8), 652 (7), 653 (12), 686 (8); Xavier Filho, L. 78 (10); Webster, G. L. 25626 (1). 